\title{
From water striders to water bugs: The molecular diversity of aquatic Heteroptera (Gerromorpha, Nepomorpha) of Germany based on DNA barcodes
}

Nadine Havemann ${ }^{1,2}$, Martin M. Gossner ${ }^{3}$, Lars Hendrich ${ }^{4}$, Jèrôme Morinière ${ }^{5}$, Rolf Niedringhaus ${ }^{6}$, Peter $^{4}$ Schäfer ${ }^{7}$, Michael J. Raupach ${ }^{\text {Corresp. } 1,2}$

${ }^{1}$ Fakultät V, Institut für Biologie und Umweltwissenschaften (IBU), Carl von Ossietzky Universität Oldenburg, Oldenburg, Lower Saxony, Germany

2 German Centre of Marine Biodiversity, Senckenberg Nature Research Society, Wilhelmshaven, Lower Saxony, Germany

3 Forest Entomology, Swiss Federal Institute for Forest, Snow and Landscape Research, Birmensdorf, Switzerland

4 Sektion Insecta varia, Bavarian State Collection of Zoology, Munich, Bavaria, Germany

${ }^{5}$ Taxonomic coordinator - German Barcode of Life (GBOL), Bavarian State Collection of Zoology, Munich, Bavaria, Germany

6 Department of Biology, Earth and Environmental Sciences, Carl von Ossietzky Universität Oldenburg, Oldenburg, Lower Saxony, Germany

7 B.U.G.S. (Biologische Umwelt-Gutachten Schäfer), Telgte, North-Rhine Westphalia, Germany

Corresponding Author: Michael J. Raupach

Email address: michael.raupach@rub.de

With about 5,000 species worldwide, the Heteroptera or true bugs are the most diverse taxon among the hemimetabolous insects in aquatic and semi-aquatic ecosystems. Species may be found in almost every freshwater environment and have very specific habitat requirements, making them excellent bioindicator organisms for water quality. However, a correct determination by morphology is challenging in many species groups due to high morphological variability and polymorphisms within, but low variability between species. Furthermore, it is very difficult or even impossible to identify the immature life stages or females of some species, e.g. of the corixid genus Sigara. In this study we tested the effectiveness of a DNA barcode library to discriminate species of the Gerromorpha and Nepomorpha of Germany. We analyzed about 700 specimens of 67 species, with 63 species sampled in Germany, covering more than $90 \%$ of all recorded species. Our library included various morphological similar taxa, e.g. species within the genera Sigara and Notonecta as well as water striders of the genus Gerris. Fifty-five species (82\%) were unambiguously assigned to a single Barcode Index Number (BIN) by their barcode sequences, whereas BIN sharing was observed for 10 species. Furthermore, we found monophyletic lineages for 52 analyzed species. Our data revealed interspecific K2P distances with below $2.2 \%$ for 18 species. Intraspecific distances above $2.2 \%$ were shown for 11 species. We found evidence for hybridization between various corixid species (Sigara, Callicorixa), but our molecular data also revealed exceptionally high intraspecific distances as a consequence of distinct mitochondrial lineages for Cymatia coleoptrata and for the pygmy backswimmer Plea minutissima. Our study clearly demonstrates the 
usefulness of DNA barcodes for the identification of the aquatic Heteroptera of Germany and adjacent regions. In this context, our data set represents an essential baseline for a reference library for bioassessment studies of freshwater habitats using modern highthroughput technologies in the near future. The existing data also opens new questions regarding the causes of observed low inter- and high intraspecific genetic variation and furthermore highlight the necessity of taxonomic revisions for various taxa, combining both molecular and morphological data. 
1 From water striders to water bugs: The molecular diversity of aquatic Heteroptera

2 (Gerromorpha, Nepomorpha) of Germany based on DNA barcodes

4 Nadine Havemann ${ }^{1,2}$, Martin M. Gossner ${ }^{3}$, Lars Hendrich ${ }^{4}$, Jérôme Morinière ${ }^{5}$, Rolf

5 Niedringhaus $^{6}$, Peter Schäfer ${ }^{7}$, Michael J. Raupach ${ }^{1,2}$

6

$7{ }^{1}$ Institute for Biology and Environmental Sciences, Carl von Ossietzky University Oldenburg,

826111 Oldenburg, Germany.

$9 \quad{ }^{2}$ German Centre of Marine Biodiversity (DZMB), Senckenberg am Meer, 26382

10 Wilhelmshaven, Germany.

$11{ }^{3}$ Forest Entomology, Swiss Federal Research Institute WSL, Zürcherstrasse 111, 8903

12 Birmensdorf, Switzerland.

$13{ }^{4}$ Sektion Insecta varia, Bavarian State Collection of Zoology (SNSB - ZSM), 81247 München,

14 Germany.

$15{ }^{5}$ Taxonomic coordinator - German Barcode of Life (GBOL), Bavarian State Collection of 16 Zoology (SNSB - ZSM), 81247 München, Germany.

$17{ }^{6}$ Department of Biology, Earth and Environmental Sciences, Carl von Ossietzky University

18 Oldenburg, PO Box 2503, 26111 Oldenburg, Germany.

$19{ }^{7}$ B.U.G.S. (Biologische Umwelt-Gutachten Schäfer), 48291 Telgte, Germany.

20

21 Corresponding Author:

22 Michael J. Raupach ${ }^{1,2}$

$23{ }^{1}$ Carl-von-Ossietzky-Straße 9-11, Oldenburg, 26111, Germany 
242 Südstrand 44, Wilhelmshaven, 26382, Germany

25 Email address: michael.raupach@rub.de

26

\section{Abstract}

With about 5,000 species worldwide, the Heteroptera or true bugs are the most diverse taxon among the hemimetabolous insects in aquatic and semi-aquatic ecosystems. Species may be found in almost every freshwater environment and have very specific habitat requirements, making them excellent bioindicator organisms for water quality. However, a correct determination by morphology is challenging in many species groups due to high morphological variability and polymorphisms within, but low variability between species. Furthermore, it is

34 very difficult or even impossible to identify the immature life stages or females of some species, e.g. of the corixid genus Sigara. In this study we tested the effectiveness of a DNA barcode library to discriminate species of the Gerromorpha and Nepomorpha of Germany. We analyzed about 700 specimens of 67 species, with 63 species sampled in Germany, covering more than $90 \%$ of all recorded species. Our library included various morphological similar taxa, e.g. species within the genera Sigara and Notonecta as well as water striders of the genus Gerris. Fifty-five species (82\%) were unambiguously assigned to a single Barcode Index Number (BIN)

41 by their barcode sequences, whereas BIN sharing was observed for 10 species. Furthermore, we

42 found monophyletic lineages for 52 analyzed species. Our data revealed interspecific K2P

43 distances with below $2.2 \%$ for 18 species. Intraspecific distances above $2.2 \%$ were shown for 11

44 species. We found evidence for hybridization between various corixid species (Sigara,

45 Callicorixa), but our molecular data also revealed exceptionally high intraspecific distances as a 46 consequence of distinct mitochondrial lineages for Cymatia coleoptrata and for the pygmy

47 backswimmer Plea minutissima. Our study clearly demonstrates the usefulness of DNA barcodes 
48 for the identification of the aquatic Heteroptera of Germany and adjacent regions. In this context,

49 our data set represents an essential baseline for a reference library for bioassessment studies of

50 freshwater habitats using modern high-throughput technologies in the near future. The existing

51 data also opens new questions regarding the causes of observed low inter- and high intraspecific

52 genetic variation and furthermore highlight the necessity of taxonomic revisions for various taxa,

53 combining both molecular and morphological data.

54

55 Introduction

56

Aquatic insects are the dominant invertebrate fauna element in most freshwater

57 ecosystems and are enormously variable in morphology, development, physiology, and ecology

58 (Lancaster \& Downes, 2013; Dijkstra, Monaghan \& Pauls, 2014). Among the hemimetabolous

59 insects, the Heteroptera or true bugs comprise a significant and diverse component of the world's

60 aquatic insect biota (Polhemus \& Polhemus, 2007). They are unique as a group because they

61 comprise both aquatic and terrestrial species, whereas other taxa include only species that are

62 aquatic during some life stage, for example mayflies, stoneflies, or dragonflies (Wesenberg-

63 Lund, 1943; Lancaster \& Downes, 2013; Gullan \& Cranston, 2014). Two infraorders, the

64 Gerromorpha and Nepomorpha, are considered as primarily aquatic (Polhemus \& Polhemus,

65 2007; Lancaster \& Downes, 2013; Gullan \& Cranston, 2014; Henry, 2017). With more than

66 4,400 described species worldwide (Henry, 2017), aquatic Heteroptera are well-known for

67 utilizing an exceptionally broad range of habitats, ranging from the marine and intertidal to the

68 arctic and high alpine (Polhemus \& Polhemus, 2007). They may be found in almost every

69 freshwater biotope. Approximately 120 species of the Gerromorpha and 230 species of the

70 Nepomorpha are known from the Palearctic region (Polhemus \& Polhemus, 2007). For 
71 Germany, 47 species of the Nepomorpha and 22 species belonging to the Gerromorpha have

72 been recorded so far (Wachmann, Melber \& Deckert, 2006; Strauss \& Niedringhaus, 2014).

74 adaptations to their aquatic environment. For instance, nepomorphan true bugs have a

75 streamlined body, natatorial legs and short antennas, whereas gerromorphan species are well-

76 known for their long slender legs which operate as motive (middle leg) and rudder (hind legs),

77 allowing them to operate on the water surface (e.g. Wesenberg-Lund, 1943; Andersen, 1982;

78 Lancaster \& Downes, 2013; Gullan \& Cranston, 2014) (Fig. 1). Furthermore, a reduction, loss, 79 and/or polymorphism of wings can be observed in many taxa, which is controlled by environmental conditions and genetic factors (e.g. Zera, Innes \& Saks, 1983; Muraji, Miura \&

81 Nakasuji, 1989; Spence \& Andersen, 1994). With the exception of the omnivorous Corixidae, all 82 aquatic true bugs are predators, feeding on any organism that can be subdued by the injection of 83 a venom cocktail consisting of various toxins and proteolytic enzymes (Polhemus \& Polhemus, 84 2007). On the other hand they serve as important prey for numerous fish and other organisms at 85 higher trophic levels (e.g. McCafferty, 1981; Zimmermann \& Spence, 1989; Hutchinson, 1993; 86 Klecka 2014; Boda et al., 2015).

87 Due to their general high abundance in many freshwater systems, their great value as 88 bioindicators of water quality and their unique morphological and ecological specializations for 89 exploiting specialized microhabitats, these groups has been in the focus of entomological and 90 ecological research for a long time (e.g. Hufnagel, Bakonyi \& Vásárhelyi, 1999; Polhemus \& 91 Polhemus, 2007; Whiteman \& Sites, 2008; Skern, Zweimüller \& Schiemer, 2010). Nevertheless, 92 as a result of their highly similar morphology, the determination of various species is quite 93 difficult and requires the help of experienced taxonomists. Furthermore, it is very difficult or 
94 even impossible to identify nymphal stages or females of some species, e.g. some species of the 95 genus Sigara Fabricius, 1775. In term of males of the Corixidae, typical diagnostic traits include 96 the shape and size of the tarsus of the first leg (pala), the arrangement of pala pegs, and the 97 morphology of the genitalia (e.g. Jansson, 1986; Savage, 1989). Because aquatic Heteroptera are of high importance for ecological and conservational studies, however, the correct species identification is essential (e.g. Hufnagel, Bakonyi \& 100 Vásárhelyi, 1999; Whiteman \& Sites, 2008; Skern, Zweimüller \& Schiemer, 2010). This is

101 especially true for juveniles and females which can, depending on the life history of a species, 102 dominate within a population over a given period of a year (e.g. Barahona, Millan \& Velasco, 103 2005; Pfenning \& Poethke, 2006; Wachmann, Melber \& Deckert, 2006). In the last few years, new molecular and genomic approaches have become more and more popular to overcome possible drawbacks of this traditional and morphology-based way of species assessment. Given the recent technological advancement of DNA-based methods, in 107 particular in the field of modern high-throughput technologies (e.g. Heather \& Chain, 2016), it is expected that such techniques will gradually replace traditional field and lab procedures in bioassessment studies over the coming ten to fifteen years (Leese et al., 2016). For example, the EU COST Action CA15219 on "Developing new genetic tools for bioassessment of aquatic 111 ecosystems in Europe" - or DNAqua-Net (http://dnaqua.net/) - aims to accelerate the use of 112 DNA-based approaches for the monitoring and assessment of aquatic habitats (Leese et al., 113 2016). Following these considerations, the analysis of single specimens, bulk samples or 114 environmental DNA will be performed routinely as part of modern species diversity assessment 115 studies (e.g. Yu et al., 2012; Scheffers et al., 2012; Cristescu, 2014; Kress et al., 2015; Creer et 116 al., 2016). However, the effectiveness of all these approaches relies highly on comprehensive 
117 sequence libraries that act as valid references (e.g. Brandon-Mong et al., 2015; Creer et al.,

118 2016). In this context, DNA barcoding represents undoubtedly the most prominent and popular

119 approach using sequence data for valid species identification (e.g. Hajibabaei et al., 2007; Miller

120 et al., 2016). The concept of DNA barcoding relies on the postulate that the interspecific genetic

121 variation is higher than the intraspecific variation of the selected marker (Hebert, Ratnasingham

$122 \&$ deWaard, 2003; Hebert et al., 2003). As a consequence, every species is characterized by a

123 unique DNA barcode cluster. For animals, an approximately 650 base-pair fragment of the

124 mitochondrial cytochrome $c$ oxidase subunit I (COI) gene was proposed as the global standard

125 for the identification of unknown specimens in terms of a given classification (sensu Hebert,

126 Ratnasingham \& deWaard, 2003; Hebert et al., 2003). However, it should be noted that various

127 problems may affect the use of mitochondrial DNA, e.g. recent speciation events (e.g. Balvín et

128 al., 2012; Raupach et al., 2014), heteroplasmy (e.g. Boyce, Zwick \& Aquadro, 1989; Kavar et al.,

129 2006; Kmiec, Woloszynska \& Janska, 2006), incomplete lineage sorting (e.g. Petit \& Excoffier,

130 2009), (introgressive) hybridization (e.g. Jansson, 1979a; 1979b; Calabrese, 1982; Spence \&

131 Wilcox, 1986; Wilcox \& Spence, 1986; Savage \& Parkin, 1998; Raupach et al., 2014), the

132 presence of alpha-proteobacteria as Wolbachia within terrestrial arthropods (Werren, Zhang \&

133 Guo, 1995; Xiao et al., 2011; Werren, Baldo \& Clark, 2008), and the existence of mitochondrial

134 pseudogenes (e.g. Leite, 2012; Song, Moulton \& Whiting, 2014). Nevertheless, a vast number of

135 studies across a broad range of different animals demonstrate the efficiency of DNA barcoding

136 (e.g. Spelda et al., 2011; Hausmann et al., 2013; Hendrich et al., 2015; Lin, Stur \& Ekrem, 2015;

137 Raupach et al., 2015; Barco et al., 2016; Coddington et al., 2016; Morinière et al., 2017).

138 Despite the fact that more than 45,000 species of true bugs have been described

139 worldwide until now (Henry, 2017), the number of studies analyzing the usefulness of DNA 
140 barcodes to discriminate species of this highly diverse insect taxon is still low. Some studies

141 focus on selected species (Rebijith et al., 2012; Zhou et al., 2012; Lis, Lis \& Ziaja, 2013), other

142 on specific families (Grebennikov \& Heiss, 2014; Kaur \& Sharma, 2017), whereas four

143 publications provide a greater representation of various families (Park et al., 2011; Jung, Duwal

$144 \&$ Lee, 2011; Raupach et al., 2014; Tembe, Shouche \& Ghate, 2014). However, all these studies

145 focused primarily on terrestrial species, analyzing just small number of species belonging to the

146 Gerromorpha and/or Nepomorpha (Park et al., 2011; Jung, Duwal \& Lee, 2011; Raupach et al.,

147 2014). To our knowledge, only two publications analyzed aquatic true bugs specifically until

148 now: Castanhole et al. (2013) investigated the variability of 17 barcode sequences of a few

149 species from Brazil, whereas Ebong et al. (2016) successfully tested the usefulness of DNA

150 barcodes to discriminate various species from Cameroon.

151 The aim of this study was to build-up a baseline for a comprehensive library of DNA

152 barcodes for aquatic Heteroptera (Gerromorpha, Nepomorpha) of Central Europe with a focus on

153 the German fauna and to test the efficiency of DNA barcodes to discriminate the analyzed

154 species. Moreover, our study provides the first thorough molecular study of the aquatic

155 Heteroptera of Germany. In doing so, we analyzed more than 700 DNA barcodes representing

156 more than 60 species. Our library included various morphological similar taxa, e.g. species of the

157 genera Sigara Fabricius, 1775 and Notonecta Linnaeus, 1758 as well as water striders of the

158 genus Gerris Fabricius, 1794 from different localities in Germany. In addition to this we added

159 various specimens from other European countries for comparison, e.g. specimens of the

160 expansive small-bodied backswimmer Anisops sardeus Herrich-Schaeffer, 1849 (Berchi, 2011;

161 Klementová \& Svitok, 2014). 


\section{Material \& Methods}

\section{Species collection and identification}

All analyzed Gerromorpha and Nepomorpha were collected between the years 2003 and

2017. Most of them were adults $(n=584 ; 96.8 \%)$. Specimens were stored in ethanol (96\%)

Niedringhaus, 2014) based on the most recent taxonomic classification (Aukema \& Rieger, 1995). All specimens were carefully checked multiple times by some of the authors in order to prevent a misidentification. For our analysis we also included 109 DNA barcodes of aquatic bugs identification was verified by the authors for comparison (Raupach et al., 2014). Most of the analyzed bug specimens were collected in Germany $(n=616: 86.5 \%)$, but various individuals were sampled in Austria (37; 5.2\%), Greece (20;2.8\%), Spain (16;2.3\%), Switzerland (8; 1.1\%), Italy (7; 1.0\%), Poland (6; 0.8\%), and Portugal (2;0.3\%) for comparison (Fig. 2). In this context

177 we also included specimens from four species that are not recorded for Germany: I. Anisops

178 sardeus Herrich-Schaeffer, 1849, $(n=5)$ from Greece, II. Mesovelia vittigera Horváth, $1895(n=$ 179 4) from Greece, III. Sigara dorsalis (Leach, 1817) $(n=1)$ from Switzerland, and IV.Velia 180 currens (Fabricius, 1794) $(n=3)$ from Switzerland. The total data set consisted of 712 DNA 181 barcodes with 63 species that are documented for Germany. Furthermore, the number of 182 analyzed specimens per species ranged from one (8 species) to a maximum of 41 for Notonecta 183 glauca Linnaeus, 1758. 
187 Biodiversity Research (Senckenberg am Meer) in Wilhelmshaven, the Carl von Ossietzky

188 University of Oldenburg, or the Bavarian State Collection of Zoology in Munich (SNSB-ZSM).

189 Following the guidelines of DNA barcoding studies (Ratnasingham \& Hebert, 2007), all species

190 were documented by photographs before molecular work started. In the majority of the studied

191 animals, all legs of one side of the body were dissected and used for DNA extraction. In case of

192 larger specimens of the genera Notonecta Linneaus, 1758, Ilyocoris Stål, 1861, Ranatra

193 Fabricius, 1790, Nepa Linnaeus, 1758, and Aphelocheirus Westwood, 1833, however, only one

194 leg was used. For some very small specimens with a body length $<3 \mathrm{~mm}$, e.g. species of the

195 genus Microvelia Westwood, 1834, complete specimens were used for DNA extraction. All voucher specimens as well as DNA extracts are stored in a local collection at the Carl von Ossietzky University of Oldenburg.

The DNA extraction was performed using the NucleoSpin Tissue Kit by Macherey and 199 Nagel (Düren, Germany), following the extraction protocol. Polymerase chain reaction (PCR) has been used for amplifying the COI barcode fragment by using the established primer pairs LCO1480/HCO2198 (Folmer et al., 1994), LCO1480/NANCY (Simon et al., 1994), jgLCO1490/jgHCO2198 (Geller et al., 2013), or LepF1/LepR1 (Hebert et al., 2004) for most

203 specimens. For various specimens of the Gerromorpha, however, a new specific forward primer 204 HETF1 (5'-ATG AAT TAT TCG AAT TGA AAT AGG-3') was designed and used in 205 combination with $\mathrm{HCO} 2198$ for amplification, resulting in a somewhat smaller fragment with a 206 length of 579 base pairs (bp) of the barcode region. All primers were modified with M13 forward 207 and reverse tails to provide defined base sequences for sequencing (see Ivanova et al., 2007; 208 Khalaji-Pirbalouty \& Raupach, 2014). 
210 (GE Healthcare, Buckinghamshire, UK) in a total volume of $20 \mu$, containing $17.5 \mu 1$ sterile

211 molecular grade $\mathrm{H}_{2} \mathrm{O}, 2 \mu \mathrm{l}$ DNA template with an DNA amount between 2 to $150 \mathrm{ng} / \mu 1$ and 0.25

$212 \mu \mathrm{l}$ of each primer $(20 \mathrm{pmol} / \mu \mathrm{l})$. The PCR thermal conditions included an initial denaturation at

$21394{ }^{\circ} \mathrm{C}(5 \mathrm{~min})$, followed by 38 cycles at $94{ }^{\circ} \mathrm{C}$ (denaturation, $\left.45 \mathrm{~s}\right), 48{ }^{\circ} \mathrm{C}$ (annealing, $\left.45 \mathrm{~s}\right), 72$

$214{ }^{\circ} \mathrm{C}$ (extension, $80 \mathrm{~s}$ ), and a final extension step at $72{ }^{\circ} \mathrm{C}(7 \mathrm{~min})$. All PCR amplification reactions

215 were conducted using an Eppendorf Mastercycler Pro system (Eppendorf, Hamburg, Germany).

216 Negative and positive controls were included with each round of reactions. Two $\mu$ l of the

217 amplified products were verified for size conformity by electrophoresis in a 1\% agarose gel with

218 GelRed or SYBR Green using commercial DNA size standards, whereas the remaining PCR

219 product was purified with the NucleoSpin Gel and PCR Clean-up Kit (Macherey-Nagel, Düren,

220 Germany). Purified PCR products were cycle-sequenced and sequenced in both directions at a

221 contract sequencing facility (GATC, Konstanz, Germany) using the given M13 tail sequences.

222 Double stranded sequences became assembled and checked for mitochondrial pseudogenes

223 (numts) analyzing the presence of stop codons, frameshifts as well as double peaks in

224 chromatograms with the Geneious program package version 7.0.4 (Biomatters, Auckland, New

225 Zealand) (Kearse et al., 2012). Ambiguous parts at the $5^{\prime}$-end or 3 '-end of the sequences were

226 removed. For verification, BLAST (nBLAST, search set: others, program selection: megablast)

227 and/or BOLD (identification engine; species level barcode records) searches were performed to

228 confirm the identity of all new sequences as bug sequences based on already published

229 sequences.

230 Detailed voucher information, taxonomic classifications, photos, DNA barcode

231 sequences, used primer pairs and trace files (including their quality) are publicly accessible 
232 through the public data set "DS-BAHCE Barcoding Aquatic Heteroptera of Central Europe"

233 (Dataset ID: dx.doi.org/10.5883/DS-BAHCE) on the Barcode of Life Data Systems workbench

234 (BOLD; www.boldsystems.org) (Ratnasingham \& Hebert, 2007). All new barcode data were

235 also deposited in GenBank (MG665389-MG665993).

236

\section{DNA barcode analysis}

238 We analyzed intra- and interspecific distances of the studied aquatic Heteroptera using

239 the provided analytical tools of the BOLD workbench (align sequences: BOLD aligner;

240 ambiguous base/gap handling: pairwise deletion) based on the Kimura 2-parameter model of

241 sequence evolution (K2P; Kimura, 1980). Furthermore, all analyzed COI sequences became

242 subject to the Barcode Index Number (BIN) system implemented in BOLD which clusters DNA

243 barcodes in order to generate operational taxonomic units that closely correspond to species

244 (Ratnasingham \& Hebert, 2013). We used a recommended threshold of 2.2\% for a rough

245 differentiation of intraspecific as well as interspecific K2P distances (Ratnasingham \& Hebert, 246 2013).

247 A Neighbor Joining cluster analysis (NJ; Saitou \& Nei, 1987) was performed for all

248 studied species for a graphical representation of the genetic differences between sequences and

249 clusters of sequences using MEGA v7.0.18 (Kumar, Stecher \& Tamura, 2016). The K2P model

250 was chosen as the model for sequence evolution for comparison purposes with previous studies.

251 For validation, non-parametric bootstrap support values were obtained by resampling and

252 analyzing 1,000 replicates (Felsenstein, 1985). All analysis were based on an alignment that was 253 generated using MUSCLE (Edgar, 2004) implemented in MEGA v7.0.18 for all studied barcode 254 sequences. Additionally, statistical maximum parsimony networks were constructed exemplarily 
255 for species with interspecific distances ranging from zero to $1 \%$ (see Table 1) by using TCS

256 networks (Clement, Posada \& Crandall, 2002) as part of the software package of PopArt v.1.7

257 (Leigh \& Bryant, 2015). Such networks allow the identification of haplotype sharing between

258 species as a consequence of recent speciation and/or on-going hybridization processes (e.g.

259 Raupach et al., 2010; Raupach et al., 2014).

260

261 Results

262 Our analyzed DNA barcode library comprised 63 species that are documented for

263 Germany, representing 91\% of the known aquatic bug species diversity of this country

264 (Nepomorpha: $n=43(92 \%)$; Gerromorpha: $n=20(91 \%)$ ), and additional four species that were

265 collected in other countries and not recorded for Germany. In total, we generated 603 new

266 barcodes of 64 species. The complete alignment of all analyzed sequences $(n=712)$ had a length

267 of $658 \mathrm{bp}$, with fragments lengths ranging from a minimum of $366 \mathrm{bp}$ to the full barcode

268 fragment size of $658 \mathrm{bp}$. For some studied specimens of Cymatia coleoptrata (Fabricius, 1777)

269 ( $n=22)$, our analysis revealed two characteristic deletions of 39 (alignment position: $110-148$ )

270 and nine nucleotides $(629-637)$ for all studied specimens (Fig. S1). Average base frequencies

271 were $\mathrm{A}=32 \%, \mathrm{C}=17 \%, \mathrm{G}=16 \%$, and $\mathrm{T}=35 \%$. For eight species only one barcode sequence

272 was generated (Table 1). Intraspecific distances ranged from zero to maximum values of $8.3 \%$

273 (Plea minutissima Leach, 1817) and 9.44\% (Cymatia coleoptrata) (Table 1). Maximum

274 intraspecific pairwise distances with values $>2.2 \%$ were found for 11 species (Table 1 ). In terms

275 of interspecific divergence, values ranged from zero to $18.58 \%$, with 18 species pairs having

276 values $<2.2 \%$ (Table 1). We found interspecific distances below $1 \%$ for 9 species. Unique BINs

277 were recorded for 55 species, whereas two BINs were identified for 10 species (Table 1). For 
278 two species that were represented only by one specimen, namely Arctocorisa germari (Fieber,

279 1848) and Corixa dentipes Thompson, 1869, our sequences did not have the required fragment

280 length of at least $400 \mathrm{bp}$ to fulfill the criteria for BIN assignment. As consequence, no BINs were

281 available for these two species.

282 Our NJ analysis based on K2P distances revealed two large and distinct clusters,

283 separating all analyzed Gerromorpha and all Nepomorpha specimens from each other (Fig. S2).

284 For a better presentation, the topology has been split on this basis and shown in two figures

285 (Gerromorpha: Fig. 3, Nepomorpha: Fig. 4). We found non-overlapping clusters with bootstrap

286 values $>90 \%$ for 57 species $(85 \%$ ) (Fig. 3; 4). Of the analyzed 59 species with more than one

287 specimen, $52(88 \%)$ were monophyletic, $3(5 \%)$ paraphyletic, and 4 (7\%) polyphyletic (Table 1, 288 Fig S2).

289 The statistical maximum parsimony network analysis of species with interspecific

290 distances below 1\% revealed a close relationship between Gerris asper (Fieber, 1860) $(n=1)$

291 and Gerris lateralis Schummel, $1832(n=2)$ (Fig. 5). We found three haplotypes with a

292 frequency of 1 (singletons) that were separated by only one or two mutational steps, with

293 haplotype h1 (Gerris asper) connected with h2 (Gerris lateralis), which was in turn connected

294 with haplotype h3 (Gerris lateralis). A similar situation was observed for Sigara limitata

295 (Fieber, 1848) $(n=2)$ and Sigara semistriata (Fieber, 1848) $(n=5)($ Fig. 5). Three different

296 haplotypes were identified, with h1 representing all studied specimens of Sigara semistriata.

297 Both unique haplotypes of Sigara limitata (h2, h3) were directly connected to this haplotype by

298 two or three mutational steps. In the case of Callicorixa praeusta (Fieber, 1848) $(n=23)$ and

299 Callicorixa producta (Reuter, 1880) $(n=1)$ we found five different haplotypes (Fig. 5), with h1

300 representing the dominant haplotype which includes 19 specimens of Callicorixa praeusta and 
301 the only specimen of Callicorixa producta. All other four haplotypes (h2-h5) were only scored in

302 one specimen and connected with h1 by one or two mutational steps. A much more complex

303 network was revealed for Sigara distincta (Fieber, 1848) ( $n=7)$, Sigara falleni (Fieber, 1848) (n

304 = 12), and Sigara iactans Jansson, $1983(n=12)$ (Fig. 6). We identified 16 different haplotypes

305 in total, with six haplotypes (h1-h6) shared by more than one specimen. Three of these

306 haplotypes (h2, h3, h5) were shared by specimens of Sigara falleni and Sigara iactans.

307 Furthermore, haplotypes of both previously mentioned species were randomly distributed within

308 the network. In many cases, haplotypes of Sigara falleni were separated merely by two

309 mutational steps from haplotypes of Sigara iactans (e.g. h6 and h13) and vice versa. We found

310 four singletons for Sigara falleni and five for Sigara iactans. In contrast to these two species, we

311 identified only two haplotypes (h1, h8) for the seven analyzed specimens of Sigara distincta.

312 Moreover, most specimens $(n=6)$ were identical (h1) and located at the periphery of the

313 network. The other haplotype (h8), a singleton collected among others at Apen (Lower Saxony),

314 was separated by more than 25 mutational steps from the network and represents the most

315 isolated haplotype in this network by far. Therefore, Sigara distincta shared no haplotypes with

316 other species.

318 Discussion

319 Our comprehensive DNA barcode library represents an important step for the molecular 320 characterization of the freshwater fauna in Central Europe and adjacent regions. As COI

321 sequences are used routinely in phylogeographic, phylogenetic and evolutionary studies as well,

322 our data can be also implemented in projects analyzing the genetic variation of species in relation

323 to historical, geographical and ecological factors (Galactos, Cognato \& Sperling, 2002; 
324 Damgaard, 2005; Damgaard, 2008b; Gagnon \& Turgeon, 2010; Ye et al., 2016). Unique BINs

325 were found for 55 species, allowing a valid identification of $82 \%$ of the analyzed 67 species.

326 Distinct and monophyletic lineages were revealed for 52 species (78\%). Our study also indicates

327 the need of further detailed taxonomic revisions, using state-of-the-art methods for a fine-scaled

328 characterization (Raupach et al., 2016). This is especially true for the species-rich family

329 Corixidae. In the following we will discuss noticeable species with high intraspecific and/or low 330 interspecific distances more in detail.

331

332 Interspecific K2P distances with values below 2.2\%

The efficiency of DNA barcoding highly depends on distinct mitochondrial lineages,

334 ideally coupled with moderate to high genetic interspecific distances. If sister species, however, 335 have low interspecific distances and haplotype sharing as a result of a recent ancestry and/or 336 ongoing gene flow, DNA barcoding will fail (e.g. Tautz et al., 2003; Frezal \& Leblois, 2008;

337 Raupach \& Radulovici, 2015). For the analyzed species of the Gerromorpha and Nepomorpha, 338 minimum interspecific K2P distances with values below 2.2\% were found for 18 species (Table 339 1). Distance values ranged from $0 \%$ (four species: Callicorixa praeusta (Fieber, 1848),

340 Callicorixa producta (Reuter, 1880), Sigara falleni (Fieber, 1848), Sigara iactans Jansson, 1983)

341 to $2.11 \%$ (Sigara venusta (Douglas \& Scott, 1869)). Distinct monophyletic clusters were 342 revealed for Notonecta obliqua Thunberg, 1787 and Notonecta glauca Linnaeus, 1758 (1.08\%), 343 Notonecta lutea Müller, 1776 and Notonecta reuteri Hungerford, 1928 (1.24\%), Sigara dorsalis

344 (Leach, 1817) and Sigara striata (Linnaeus, 1758) (1.71\%) (but see Savage and Parkin, 1998), 345 and Sigara venusta (Douglas \& Scott, 1869) and Sigara limitata (Fieber, 1848)/Sigara 346 semistriata (Fieber, 1848) (2.11\%), indicating a close relationship of these species pairs with 
347 distinct lineages (Table 1). Furthermore, the analyzed specimen of Arctocorisa germari (Fieber,

348 1848) was nested in the paraphyletic cluster of Arctocorisa carinata (C. R. Sahlberg, 1819)

$349(1.03 \%)$ (Fig. S1). In this context it should be noted that experimental crosses gave viable

350 hybrids between both Arctocorisa species with intermediate characters (Jansson, 1979). These

351 examples show that recent speciation events as well as hybridization may represent important

352 processes in these groups. Future studies including more specimens and other genetic markers

353 should be conducted to resolve the eco-evolutionary events leading to the low interspecific

354 variation. Species pairs with interspecific K2P distances $<1 \%$ will be discussed more in detail

355 below.

356

357 Species pairs with interspecific distances below 1\%

358 I. Gerris asper (Fieber, 1860) and Gerris lateralis Schummel, 1832

$359 \quad$ From a morphological perspective, both species are very similar (e.g. Wagner \&

360 Zimmermann, 1955; Wachmann, Melber \& Deckert, 2006). Not surprisingly, Gerris asper is

361 suggested as a south-eastern vicariant of its boreo-montane sister species Gerris lateralis

362 (Jeziorski et al., 2012). Whereas Gerris lateralis has a distribution ranging from Europe to the

363 Far East of Russia, Gerris asper is found in Southern and Central Europe, extending to

364 Afghanistan (Jeziorski et al., 2012). In spite of the fact that our sample sizes were very small

365 (Gerris asper: $n=1$, Gerris lateralis: $n=2$ ), our molecular data set clearly support the proposed

366 close relationship of both water striders species (Fig. 5, Table 1). Future studies including more

367 specimens covering a larger geographic range are needed to test whether both taxa represent

368 distinct lineages or hybridization still takes place as it is known from other species of this genus

369 (e.g. Calabrese, 1982). 


\section{Sigara limitata (Fieber, 1848) and Sigara semistriata (Fieber, 1848)}

Both species belong to the subgenus Retrocorixa Walton, 1940 and have a similar

373 distribution, ranging from Europe eastwards to Siberia (Jansson, 1986; Wachmann, Melber \&

374 Deckert, 2006; Coulianos, Økland \& Økland, 2008). A close relationship as it has been indicated

375 by our data has not been proposed yet. In contrast to our results, morphological characters

376 suggest Sigara venusta (Douglas \& Scott, 1869) as sister species of Sigara semistriata (see

377 Jansson, 1986). As part of our study, Sigara venusta represents the sister species of Sigara

378 limitata and Sigara semistriata with a distance of $2.11 \%$ (Fig. 5, Table 1). Due to the fact that

379 neither Sigara limitata nor Sigara semistriata were monophyletic and the observed interspecific

380 distances were very low (0.15\%) (Table 1$)$, we suggest a recent ancestry of both species. Hybrids

381 are currently not known. Future studies are needed to verify this hypothesis.

382

383

III. Callicorixa praeusta (Fieber, 1848) and Callicorixa producta (Reuter, 1880)

The genus Callicorixa White, 1873 includes five medium sized species $(6-8 \mathrm{~mm})$ that

are recorded for Europe, with two species documented in Central Europe. Specimens of

Callicorixa praeusta can be found throughout most Europe except the Mediterranean region

387

reaching to the Far East of Russia, whereas the distribution of Callicorixa producta ranges from

the Northern parts of Central Europe to Fennoscandia, Northern Russia, Kazakhstan, Mongolia,

and Siberia (Jansson, 1986; Wachmann, Melber \& Deckert, 2006; Coulianos, Økland \& Økland,

390 2008). Most identification keys for this genus rely largely on the shape and intensity of dark areas of the hind tarsus 1 (Jansson, 1986; Savage 1989; Strauss \& Niedringhaus, 2014). While

392 this morphological trait is fairly good for the determination of most typical specimens, existing 
393 variation is rather wide, making it unreliable in many cases (Jansson, 1986). Similar to other

394 species, our DNA barcode data give evidence for a recent ancestry or ongoing gene flow

395 between Callicorixa praeusta and Callicorixa producta (Fig. 5). However, only one (female)

396 specimen of Callicorixa producta was available, demonstrating the need for more detailed

397 studies to clarify the underlying processes.

398

399

IV. Sigara distincta (Fieber, 1848), Sigara falleni (Fieber, 1848), and Sigara iactans Jansson,

4001983

401 Some decades ago, a comprehensive revision revealed that the well-known species Sigara

402 falleni of the subgenus Subsigara Stichel, 1935 was actually a mixture of four closely related and 403 highly similar species, including Sigara iactans (see Jansson, 1983). Whereas the identification 404 of females is not always reliable, males of both species can be recognized by the shape of their 405 pala: specimens of Sigara falleni are characterized by triangular pala, whereas trapezoidal pala 406 are found for Sigara iactans (Jansson, 1983; 1986). Intermediate specimens, however, have been 407 also documented and indicate on-going hybridization between both species (Jansson, 1983;

408 1986). Water bugs of Sigara distincta are found from the British Isles through North and Central 409 Europe to Asia as far as East Siberia and Mongolia (Jansson, 1986; Savage, 1989; Coulianos, 410 Økland \& Økland, 2008). A similar distribution is known for Sigara falleni, ranging throughout 411 most of Europe eastwards to Siberia and China (Jansson, 1986; Savage, 1989; Coulianos, Økland 412 \& Økland, 2008). In contrast to both previous species, Sigara iactans is found in two disjunct 413 areas, one in North and Central Europe, and the other in Southeastern Europe (Jansson, 1986; 414 Wachmann, Melber \& Deckert, 2006). Our DNA barcode data revealed multiple haplotype 415 sharing between Sigara falleni and Sigara iactans, supporting the close relationship and on- 
416 going hybridization between both species (Fig. 6). Beside this, our results revealed a close

417 relationship of Sigara (Subsigara) distincta with Sigara falleni and Sigara iactans, as it has been

418 discussed in the past also (Jansson, 1986). However, we found no shared haplotypes yet.

419 Additional studies involving more specimens of a larger geographic region are needed to validate 420 the species status within this subgenus.

421

\section{Intraspecific K2P distances with values $>2.2 \%$}

423

Various phenomena can generate distinct lineages within DNA barcode data, e.g.

424 phylogeographic processes (e.g. Andersen et al., 2000; Damgaard 2005; 2008b; Ye et al., 2016),

425 the presence of maternally inherited endosymbionts as Wolbachia (e.g. Lis, Maryańska-

426 Nadachowska \& Kajtoch, 2015), or the existence of cryptic species (e.g. Paterson et al., 2016;

427 Jiu et al., 2017). In this context we found 11 species with intraspecific K2P distances $>2.2 \%$,

428 ranging from 2.32\% (Mesovelia vittigera Horváth, 1895) to a maximum of 9.44 (Cymatia

429 coleoptrata (Fabricius, 1777)). For most species, excluding Sigara iactans (2.67\%), Sigara

430 falleni (3.37\%), and Sigara distincta (5.77\%) (see discussion above), we are currently unable to

431 clarify the background of the observed high nucleotide distances and distinct lineages based on

432 the given data set. However, exceptionally high intraspecific distances with values $>8 \%$ were

433 found within the pygmy backswimmer Plea minutissima Leach, 1817 (8.3\%) and Cymatia

434 coleoptrata (Fabricius, 1777) (9.44\%) (Table 1). Both will be discussed more in detail.

435

436 Small and cryptic: two highly distinct DNA barcode clusters within Plea minutissima

437 Leach, 1817 
Pygmy backswimmers are small bugs, usually less than $3.5 \mathrm{~mm}$ in length and confine

439 themselves to the vegetation in which they hide and where they prey on mosquito larvae and 440 other small arthropods (Schuh \& Slater, 1995). For Europe, only one species of the Pleidae is 441 recorded, namely Plea minutissima. As part of our study we found two distinct lineages within

442 the sixteen analyzed specimens with high distances ranging from 8.1 to $8.3 \%$. Both lineages

443 were supported by high bootstrap values (99\%) (Fig. 7). Most specimens of lineage A $(n=8)$

444 were found in Brandenburg and Bavaria, but also two specimens were collected in Lower

445 Saxony (Jaderberg). In contrast to this, all specimens of lineage B $(n=8)$ were collected in

446 Lower Saxony (Jaderberg, Lingen, Norderney). Whether this surprisingly high molecular

447 diversity is a result of effects as incomplete lineage sorting (e.g. Damgaard, 2008) or whether we

448 found evidence for the existence of two sibling species (e.g. Damgaard, 2005), is not within the 449 scope of this study but clearly needs further investigation.

450

451 A currently unknown species of the genus Cymatia Flor, 1860?

452 For the genus Cymatia, three European species are documented so far: Cymatia 453 coleoptrata (Fabricius, 1777), Cymatia bonsdorffii (C. R. Sahlberg, 1819), and Cymatia 454 rogenhoferi (Fieber, 1864). In terms of a morphological identification, all species can be 455 identified according to their size and hemelytral patterns without doubt (Janssen 1986, Stoffelen 456 et al., 2013). Our study revealed two distinct lineages within the analyzed specimens of Cymatia

457 coleoptrata (lineage A and B), with a K2P distances ranging from $9.13-9.42 \%$ and bootstrap 458 support values of 99\% (Fig. 8). Whereas lineage A includes 22 specimens from Lower Saxony ( $n$ $459=21$, Lingen) and Baden-Württemberg ( $n=1$, Wolperstwende), lineage B contains two 460 specimens that were collected in Brandenburg (Voßberg). Both specimens of lineage B were 
461 small adult males with a body size between 4.3 and $4.5 \mathrm{~mm}$ and were identified using

462 morphological traits as Cymatia coleoptrata at first sight. Interestingly, their barcode sequences

463 did not have the characteristic nucleotide deletions of this species (Fig. S1). Furthermore, we

464 found no other similar sequences using the BOLD identification engine (Best ID: Cymatia

465 coleoptrata) (date of request: 2017-11-20). Unfortunately, both Cymatia vouchers were lost,

466 preventing a closer reanalysis of the specimens. Nevertheless, our results should motivate

467 heteropterologists to study more specimens of this genus, in particular from the Eastern parts of

468 Germany, in order to verify the presence of this putative new species.

469

470 Conclusion

471 In our study we lay the foundations for a comprehensive DNA barcode data set for the

472 aquatic Heteroptera in Central Europe and adjacent regions, which will act as useful reference

473 library for freshwater bioassessment studies using modern high-throughput sequencing

474 technologies. Unique BINs were revealed for 55 species, representing $82 \%$ of the analyzed 67

475 species. Furthermore, monophyletic lineages were found for 52 species (78\%). Nevertheless, our

476 molecular data highlights discordance between the generally accepted but exclusively

477 morphologically-based taxonomy and observed molecular diversity within some species of the

478 Gerromorpha and Nepomorpha. The analysis of additional specimens from other localities and of 479 other molecular markers, for example microsatellites or SNPs, will give us more insights into the 480 taxonomic status of these species as well as in the eco-evolutionary processes underlying the

481 observed genetic patterns. However, it should be kept in mind that the traditional aims of

482 taxonomy are unchanged and include various aspects, e.g. detailed high-quality descriptions and

483 delimitation of species, a classification that reflects evolution, a dynamic nomenclature, and fast 
484 and reliable identification tools. Therefore, our DNA barcode library may be considered as a

485 promoter for such studies.

486

487 Acknowledgements

488 We would like to thank Jana Deppermann and Babett Günther (both DZMB,

489 Wilhelmshaven) for their laboratory assistance. Three anonymous reviewers provided helpful

490 comments on the manuscript. We also thank Torsten Berger (Potsdam) and Reinhard Müller

491 (Berlin) for providing further specimens. Furthermore we are very grateful to Gerhard Strauss for

492 giving his permission to use the excellent photos of aquatic true bugs from www.corisa.de. We

493 are also grateful to the team of Paul Hebert in Guelph (Ontario, Canada) for their great support

494 and help and in particularly to Sujeevan Ratnasingham for developing the BOLD database

495 infrastructure and the BIN management tools.

496

497 References

498 Andersen NM. 1982. The Semiaquatic Bugs (Hemiptera, Gerromorpha). Phylogeny,

499 Adaptations, Biogeography and Classification. Klampenborg: Scandinavian Science Press Ltd.

500

501 Andersen NM, Cheng L, Damgaard J, Sperling FAH. 2000. Mitochondrial DNA sequence

502 variation and phylogeography of oceanic insects (Hemiptera: Gerridae: Halobates spp.). Marine

503 Biology 136:421-430. DOI: https://doi.org/10.1007/s002270050701.

504 
505 Aukema B, Rieger C. 1995. Catalogue of the Heteroptera of the Palaearctic Region Vol. 1:

506 Enicocephalomorpha, Dipsocoromorpha, Nepomorpha, Gerromorpha and Leptopodomorpha.

507 Amsterdam: Netherlands Entomological Society.

508

509 Balvín O, Munclinger P, Kratochvíl L, Vilímová J. 2012. Mitochondrial DNA and morphology

510 show independent evolutionary histories of bedbug Cimex lectularius (Heteroptera: Cimicidae)

511 on bats and humans. Parasitology Research 111:457-469. DOI: 10.1007/s00436-012-2862-5.

512

513 Barahona J, Millan A, Velasco. 2005. Population dynamics, growth and production of Sigara 514 selecta (Fieber, 1848) (Hemiptera, Corixidae) in a Mediterranean hypersaline stream. 515 Freshwater Biology 50:2101-2113. DOI: 10.1111/j.1365-2427.2005.01463.x.

516

517 Barco A, Raupach MJ, Laakmann S, Neumann H, Knebelsberger T. 2016. Identification of 518 North Sea molluscs with DNA barcoding. Molecular Ecology Resources 16:288-297. DOI: $519 \quad 10.1111 / 1755-0998.12440$.

520

521 Berchi GM. 2011. First record of Anisops sardeus (Hemiptera: Heteroptera: Notonectidae) in 522 Romania. North-Western Journal of Zoology 7:339-341.

523

524 Boda P, Bozóki T, Vásárhelyi T, Bakonyi G, Várbíró G. 2015. Revised and annotated checklist 525 of aquatic and semi-aquatic Heteroptera of Hungary with comments on biodiversity patterns. 526 ZooKeys 501:89-108. DOI: 10.3897/zookeys.501.8964. 
528 Boyce TM, Zwick ME, Aquadro CF. 1989. Mitochondrial DNA in the bark weevils size,

529 structure and heteroplasmy. Genetics 123:825-836.

530

531 Brandon-Mong GJ, Gan HM, Sing KW, Lee PS, Lim PE, Wilson JJ. 2015. DNA metabarcoding 532 of insects and allies: an evaluation of primers and pipelines. Bulletin of Entomological Research 533 105:717-727. DOI: 0.1017/S0007485315000681.

534

535 Calabrese DM. 1982. Hybridization between Gerris alacris Hussey and Gerris comatus Drake 536 and Hottes (Hemiptera: Heteroptera: Gerridae) in nature. Proceedings of the Entomological 537 Society of Washington 84:209-210.

538

539 Castanhole MMU, Marchesin SRC, Pereira LLV, Moreira FFF, Barbosa JF, Valério JR, Itoyama 540 MM. 2013. The first assess of the haplotypes from COI gene sequences in species of spittlebugs

541 (Cicadomorpha: Hemiptera) and aquatic true bugs (Gerromorpha and Nepomorpha: Hemiptera)

542 in Brazil. Genetics and Molecular Research 12:5372-5381. DOI: 10.4238/2013.November.7.12.

543

544 Clement M, Posada D, Crandall KA. 2000. TCS: estimating gene genealogies. Molecular

545 Ecology 9:1657-1659. DOI:10.1046/j.1365-294x.2000.01020.x.

546

547 Coddington JA, Aganrsson I, Cheng R-C, Candek K, Driskell A, Frick H, Gregorič M,

548 Kostanjšek R, Kropf C, Kweskin M, Lokovšek T, Pipan M, Vidergar N, Kunter M. 2016. DNA

549 barcode data accurately assign higher spider taxa. PeerJ 4:e2201. DOI: 10.7717/peerj.2201. 
551 Coulianos C-C, Økland J, Økland KA. 2008. Norwegian water bugs. Distribution and ecology

552 (Hemiptera-Heteroptera: Gerromorpha and Nepomorpha). Norwegian Journal of Entomology

$553 \quad 55: 179-222$.

554

555 Creer S, Deiner K, Frey S, Porazinska D, Taberlet P, Thomas WK, Potter C, Bik HM. 2016. The 556 ecologist's filed guide to sequence-based identification of biodiversity. Methods in Ecology and 557 Evolution 7:1008-1018. DOI: 10.1111/2041-210X.12574.

558

559 Cristescu ME. 2014. From barcoding single individuals to metabarcoding biological 560 communities: towards an integrative approach to the study of global biodiversity. Trends in 561 Ecology and Evolution 29:566-571. DOI: http://dx.doi.org/10.1016/j.tree.2014.08.001.

562

563 Damgaard J. 2005. Genetic diversity, taxonomy, and phylogeography of the western Palaearctic 564 water strider Aquarius najas (DeGeer) (Heteroptera: Gerridae). Insect Systematics \& Evolution 565 36:395-406. DOI: 10.1163/187631205788838537.

566

567 Damgaard J. 2008. MtDNA diversity and species phylogeny of western Palaearctic members of 568 the Gerris lacustris group (Hemiptera-Heteroptera: Gerridae) with implications for "DNA 569 barcoding" of water striders. Insect Systematics \& Evolution 39:107-120. DOI:

$570 \quad 10.1163 / 187631208788784156$.

571 
572 Damgaard J. 2008b. MtDNA diversity and phylogeography of five Palaearctic water striders

573 (Hemiptera-Heteroptera: Gerridae). In: Grozewa S, Simov N, eds. Advances in Heteroptera

574 Research. Sofia-Moscow: Pensoft Publishers, 17-30.

575

576 Dijkstra K-DB, Monagha MT, Pauls SU. 2014. Freshwater biodiversity and aquatic insect

577 diversification. Annual Review of Entomology 59:153-163. DOI:

578 https://doi.org./10.1146/annurev-ento-011613-161958.

579

580 Ebong SMA, Petit E, Le Gall P, Chen P-P, Nieser N, Guilbert E, Njiokou F, Marsollier L,

581 Guégan J-F, Pluot-Sigwalt D, Eyangoh S, Harry M. 2016. Molecular species delimitation and

582 morphology of aquatic and sub-aquatic bugs (Heteroptera) in Cameroon. PLoS ONE 11:

583 e0154905. DOI: 10.1371/journal.pone.0154905.

584

585 Edgar RC. 2004. MUSCLE: a multiple sequence alignment method with reduced time and space 586 complexity. BMC Bioinformatics 5:113. DOI: 10.1186/1471-2105-5-113.

587

588 Eyre MD, Foster GN. 1989. A comparison of aquatic Heteroptera and Coleoptera communities

589 as a basis for environmental and conservation assessments in static water sides. Journal of

590 Applied Entomology 108:355-362. DOI: 10.1111/j.1439-0418.1989.tb00468.x.

591

592 Felsenstein J. 1985. Confidence limits on phylogenies: an approach using the bootstrap.

593 Evolution 39:783-791. DOI: 10.2307/2408678. 
595 Folmer O, Black M, Hoeh W, Lutz R, Vrijenhoek R. 1994. DNA primers for amplification of

596 mitochondrial cytochrome c oxidase subunit I from diverse metazoan invertebrates. Molecular

597 Marine Biology and Biotechnology 3:294-299.

598

599 Frezal L, Leblois R. 2008. Four years of DNA barcoding: Current advances and prospects.

600 Infection, Genetics and Evolution 8:727-736. DOI: 10.1016/j.meegid.2008.05.005.

601

602 Gagnon M-C, Turgeon. 2010. Disjunct distributions in Gerris species (Insecta: Hemiptera:

603 Gerridae): an analysis based on spatial and taxonomic patterns of genetic diversity. Journal of

604 Biogeography 37:170-178. DOI: 10.1111/j.1365-2699.2009.02195.x.

605

606 Galactos K, Cognato AI, Sperling FAH. 2002. Population genetic structure of two water strider 607 species in the Ecuadorian Amazon. Freshwater Biology 47:391-399. DOI: 10.1046/j.1365-

608 2427.2002.00811.x.

609

610 Geller J, Meyer C, Parker M, Hawk H. 2013. Redesign of PCR primers for mitochondrial

611 cytochrome $c$ oxidase subunit I for marine invertebrates and application in all-taxa biotic

612 surveys. Molecular Ecology Resources 13:851-61. DOI: 10.1111/1755-0998.12138.

613

614 Grebennikov VV, Heiss E. 2014. DNA barcoding of flat bugs (Hemiptera: Aradidae) with 615 phylogenetic implications. Arthropod Systematics \& Phylogeny 72:213-219.

616 
617 Gullan PA, Cranston PS. 2014. The Insects - An outline of Entomology. Fifth Edition. Oxford:

618 Wiley-Blackwell.

619

620 Hajibabaei M, Singer GAC, Hebert PDN, Hickey DA. 2007. DNA barcoding: how it

621 complements taxonomy, molecular phylogenetics and population genetics. Trends in Genetics

622 23:167-172. DOI: https://doi.org/10.1016/j.tig.2007.02.001.

623

624 Hausmann A, Godfray HCJ, Huemer P, Mutanen M, Rougerie R, van Nieukerken EJ,

625 Ratnasingham S, Hebert PDN. 2013. Genetic patterns in European Geometrid moths revealed by

626 the Barcode Index Number (BIN) System. PLoS ONE 8:e84518. DOI:

627 https://doi.org/10.1371/journal.pone.0084518.

628

629 Hebert PDN, Cywinska A, Ball SL, deWaard JR. 2003a. Biological identifications through DNA

630 barcodes. Proceedings of the Royal Society Biological Sciences 270:313-21. DOI:

$631 \quad 10.1098 / \mathrm{rspb} .2002 .2218$.

632

633 Hebert PDN, Ratnasingham S, deWaard JR. 2003. Barcoding animal life: cytochrome $c$ oxidase

634 subunit 1 divergences among closely related species. Proceedings of the Royal Society

635 Biological Sciences 270:96-99. DOI: 10.1098/rsbl.2003.0025.

636

637 Hebert PDN, Penton EH, Burns JM, Janzen DH, Hallwachs W. 2004. Ten species in one: DNA

638 barcoding reveals cryptic species in the neotropical skipper butterfly Astraptes fulgerator. 
639 Proceedings of the National Academy of Sciences of the United States of America 101:14812-

640 14817. DOI: 10.1073/pnas.0406166101.

641

642 Hendrich L, Morinière J, Haszprunar G, Hebert PD, Hausmann A, Köhler F, Balke M. 2015. A

643 comprehensive DNA barcode database for Central European beetles with a focus on Germany:

644 adding more than 3500 identified species to BOLD. Molecular Ecology Resources 15:795-818.

645 DOI: $10.1111 / 1755-0998.12354$.

646

647 Henry TJ. 2017. Biodiversity of Heteroptera. In: Foottit RG, Adler PH, eds. Insect biodiversity:

648 Science and Society. Hoboken: Wiley, 279-335.

649

650 Hufnagel L, Bakonyi G, Vásárhelyi T. 1999. New approach for habitat characterization based on 651 species lists of aquatic and semiaquatic bugs. Environmental Monitoring and Assessment 58:305-

652 316. DOI: https://doi.org/10.1023/A:1006047130545.

653

654 Hurst GD, Jiggins FM. 2005. Problems with mitochondrial DNA as a marker in population,

655 phylogeographic and phylogenetic studies: the effects of inherited symbionts. Proceedings of the 656 Royal Society Biological Sciences 272:1525-1534. DOI: 10.1098/rspb.2005.3056.

657

658 Hutchinson G. 1993. A treatise on limnology, Vol. 4, The Zoobenthos. New York: Wiley \& Sons.

659

660 Ivanova NV, Zemlak TS, Hanner RH, Hebert PDN. 2007. Universal primer cocktails for fish 661 DNA barcoding. Molecular Ecology Notes 7:544-548. DOI: 10.1111/j.1471-8286.2007.01748.x. 
662

663 Jansson A. 1979a. Reproductive isolation and experimental hybridization between Arctocorisa 664 carinata and A. germari (Heteroptera, Corixidae). Annales Zoologici Fennici 16: 89-104. DOI: 665 http://www.jstor.org/stable/23734416.

666

667 Jansson A. 1979b. Experimental hybridization of Sigara striata and S. dorsalis (Heteroptera, 668 Corixidae). Annales Zoologici Fennici 16:105-114. DOI: http://www.jstor.org/stable/23734417. 669

670 Jansson A. 1983. Three new palaearctic species of Sigara (Subsigara) (Heteroptera, Corixidae).

671 Annales Entomologici Fennici 49:65-70.

672

673 Jansson A. 1986. The Corixidae (Heteroptera) of Europe and some adjacent regions. Acta 674 Entomologica Fennica 47:1-94.

675

676 Jeziorski P, Kment P, Ditrich T, Straka M, Sychra J, Dvořák L. 2012. Distribution of Gerris 677 asper and G. lateralis (Hemiptera: Heteroptera: Gerridae) in the Czech Republic. Klapalekiana 678 48:191-202.

679

680 Jung S, Duwal RK, Lee S. 2011. COI barcoding of true bugs (Insecta, Heteroptera). Molecular 681 Ecology Resources 11:266-270. DOI: 10.1111/j.1755-0998.2010.02945.x.

682

683 Kavar T, Pavlovčič P, Sušnik S, Meglič V, Virant-Doberlet M. 2006. Genetic differentiation of 684 geographically separated populations of the southern green stink bug Nezara viridula 
685 (Hemiptera: Pentatomidae). Bulletin of Entomological Research 96:117-128. DOI:

686 10.1079/BER2005406.

687

688 Kaur H, Sharma K. 2017. COI-based DNA barcoding of some species of Pentatomidae from 689 North India (Hemiptera: Heteroptera). Mitochondrial DNA Part A 28:756-761. DOI:

690 http://dx.doi.org/10.1080/24701394.2016.1180513.

691

692 Kearse M, Moir R, Wilson A, Stones-Havas S, Cheung M, Sturrock S, Buxton S, Cooper A, 693 Markowitz S, Thierer CDT, Ashton B, Meintjes P, Drummond A. 2012. Geneious Basic: an 694 integrated and extendable desktop software platform for the organization and analysis of 695 sequence data. Bioinformatics 15:1647-1649. DOI:

696 https://doi.org/10.1093/bioinformatics/bts 199.

697

698 Kress WJ, García-Robledo C, Uriarte M, Erickson DL. 2015. DNA barcodes for ecology, 699 evolution, and conservation. Trends in Ecology \& Evolution 30:25-35. DOI:

700 http://dx.doi.org/10.1016/j.tree.2014.10.008

701

702 Khalaji-Pirbalouty V, Raupach MJ (2014) A new species of Cymodoce Leach, 1814 (Crustacea: 703 Isopoda: Sphaeromatidae) from the Persian Gulf based on morphological and molecular 704 characteristics, with a redescription of Cymodoce tribullis from Queensland. Zootaxa 3826: 230705 254. DOI: 10.11646/zootaxa.3826.1.7.

706 
707 Kimura M. 1980. A simple method for estimating evolutionary rate of base substitutions through 708 comparative studies of nucleotide sequences. Journal of Molecular Evolution 16:111-120. DOI:

709 https://doi.org/10.1007/BF01731581.

710

711 Klecka J. 2014. The role of a water bug, Sigara striata, in freshwater food webs. PeerJ 2:e389.

712 DOI: $10.7717 /$ peerj.389.

713

714 Klementová BR, Svitok M. 2014. Anisops sardeus (Heteroptera): A new expansive species in

715 Central Europe. Biologia 69:676-680. DOI: 10.2478/s11756-014-0354-z

716

717 Kmiec B, Woloszynska M, Janska H. 2006. Heteroplasmy as a common state of mitochondrial 718 genetic information in plants and animals. Current Genetics 50:149-159. DOI:

719 https://doi.org/10.1007/s00294-006-0082-1.

720

721 Kumar S, Stecher G, Tamura K. 2016. MEGA7: Molecular Evolutionary Genetics Analysis 722 version 7.0 for bigger datasets. Molecular Biology and Evolution 33:1870-1874. DOI:

$72310.1093 / \mathrm{molbev} / \mathrm{msw} 054$.

724

725 Lancaster J, Downes BJ. 2013. Aquatic Entomology. First Edition. Oxford: Oxford University 726 Press.

727 
728 Lejzerowicz F, Esling P, Pillet L, Wildling TA, Black KD, Pawlowski J. 2015. High-throughput

729 sequencing and morphology perform equally well for benthic monitoring of marine ecosystems.

730 Scientific Reports 5:13932. DOI: 10.1038/srep13932

731

732 Leese F, Altermatt F, Bouchez A, Ekrem T, Hering D, Meissner K, Mergen P, Pawlowski J,

733 Piggott J, Rimet F, Steinke D, Taberlet P, Weigand A, Abarenkov K, Beja P, Bervoets L,

734 Björnsdóttir S, Boets P, Boggero A, Bones A, Borja Á, Bruce K, Bursić V, Carlsson J, Čiampor

735 F, Čiamporová-Zatovičová Z, Coissac E, Costa F, Costache M, Creer S, Csabai Z, Deiner K,

736 DelValls Á, Drakare S, Duarte S, Eleršek T, Fazi S, Fišer C, Flot J, Fonseca V, Fontaneto D,

737 Grabowski M, Graf W, Guðbrandsson J, Hellström M, Hershkovitz Y, Hollingsworth P,

738 Japoshvili B, Jones J, Kahlert M, Kalamujic Stroil B, Kasapidis P, Kelly M, Kelly-Quinn M,

739 Keskin E, Kõljalg U, Ljubešić Z, Maček I, Mächler E, Mahon A, Marečková M, Mejdandzic M,

740 Mircheva G, Montagna M, Moritz C, Mulk V, Naumoski A, Navodaru I, Padisák J, Pálsson S,

741 Panksep K, Penev L, Petrusek A, Pfannkuchen M, Primmer C, Rinkevich B, Rotter A, Schmidt-

742 Kloiber A, Segurado P, Speksnijder A, Stoev P, Strand M, Šulčius S, Sundberg P, Traugott M,

743 Tsigenopoulos C, Turon X, Valentini A, van der Hoorn B, Várbíró G, Vasquez Hadjilyra M,

744 Viguri J, Vitonytė I, Vogler A, Vrålstad T, Wägele W, Wenne R, Winding A, Woodward G,

745 Zegura B, Zimmermann J. 2016. DNAqua-Net: Developing new genetic tools for bioassessment 746 and monitoring of aquatic ecosystems in Europe. Research Ideas \& Outcomes 2:e11321. DOI:

$747 \quad$ 10.3897/rio.2.e11321.

748

749 Leigh JW, Bryant D. 2015. POPART: Fullfeature software for haplotype network construction.

750 Methods in Ecology and Evolution 6: 1110-1116. DOI: 10.1111/2041-210X.12410. 
752 Leite LAR. 2012. Mitochondrial pseudogenes in insect DNA barcoding: differing points of view 753 on the same issue. Biota Neotropica 12:3. DOI:

754 http://www.biotaneotropica.org.br/v12n3/en/abstract?thematic-review+bn02412032012. 755

756 Lin X, Stur E, Ekrem T. 2015. Exploring genetic divergence in a species-rich insect genus using 7572790 DNA barcodes. PLOS ONE 10:e0138993. DOI:

758 https://doi.org/10.1371/journal.pone.0138993.

759

760 Lis A, Maryańska-Nadachowska A, Kajtoch Ł. 2015. Relations of Wolbachia infection with 761 phylogeography of Philaenus spumarius (Hemiptera: Aphrophoridae) populations within and 762 beyond the Carpathian contact zone. Microbial Ecology 70:509-521. DOI: 10.1007/s00248-015$763 \quad 0570-2$.

764

765 Lis B, Lis JA, Ziaja DJ. 2013. Identification of the nymphal stages of two European seed bugs,

766 L. equestris and L. simulans (Hemiptera: Heteroptera: Lygaeidae), using DNA barcodes. Zootaxa 767 3608:147-150. DOI: http://dx.doi.org/10.11646/zootaxa.3608.2.5. 
769 Lobo J, Shokralla S, Costa MH, Hajibabaei M, Costa FO. 2017. DNA metabarcoding for high-

770 throughput monitoring of estuarine microbenthic communities. Scientific Reports 7:15618. DOI:

771 10.1038/s41598-017-15823-6.

772

773 McCafferty W. 1981. Aquatic Entomology. Boston: Science Books International.

774

775 Miller SE, Hausmann A, Hallwachs W, Janzen DH. 2016. Advancing taxonomy and

776 bioinventories with DNA barcodes. Philosophical Transactions of the Royal Society B:

777 Biological Sciences 371:20150339. DOI: http://dx.doi.org/10.1098/rstb.2015.0339.

778

779 Mohrbeck I, Raupach MJ, Martínez Arbizu P, Knebelsberger T, Laakmann S. 2015. High-

780 throughput sequencing - the key to rapid biodiversity assessment of marine Metazoa? PLoS

781 ONE 10:e0140342. DOI: https://doi.org/10.1371/journal.pone.0140342

782

783 Morinière J, Hendrich L, Balke M, Beermann AJ, König T, Hess M, Koch S, Müller R, Leese F,

784 Hebert PDN, Hausmann A, Schubart CD, Haszprunar G. 2017. A DNA barcode library for

785 Germany`s mayflies, stoneflies and caddisflies (Ephemeroptera, Plecoptera and Trichoptera).

786 Molecular Ecology Resources 17:1293-1307.

787

788 Moriniére J, Cancian de Araujo B, Lam AW, Hausmann A, Balke M, Schmidt S, Hendrich L,

789 Doczkal D, Fartmann B, Arvidsson S, Haszprunar G. 2016. Species identification in Malaise trap

790 samples by DNA barcoding based on NGS technologies and a scoring matrix. PLoS ONE

791 11:e0155497. DOI: 10.1371/journal.pone.0155497. 
793 Muraji M, Miura T, Nakasuji F. 1989. Phenological studies on the wing dimorphism of a semi794 aquatic bug, Microvelia douglasi (Heteroptera: Veliidae). Researches on Population Ecology

795 31:129-138. DOI: https://doi.org/10.1007/BF02515811.

796

797 Nieser N. 1982. De Nederlandse water- en oppervlakte wantsen (Heteroptera: Nepomorpha en 798 Gerromorpha). Wetenschappelijke mededelingen van de koninklijke Nederlandse

799 Natuurhistorische Vereniging 155:1-103. (in Dutch)

800

801 Park DS, Foottit R, Maw E, Hebert PDN. 2011. Barcoding bugs: DNA-based identification of 802 the true bugs (Insecta: Hemiptera: Heteroptera). PLoS ONE 6:e18749. DOI:

803 https://doi.org/10.1371/journal.pone.0018749.

804

805 Paterson ID, Mangan R, Downie DA, Coetzee JA, Hill MP, Burke AM, Downey PO, Henry TJ, 806 Compton SG. 2016. Two in one: cryptic species discovered in biological control agent 807 populations using molecular data and crossbreeding experiments. Ecology and Evolution 6:6139808 6150. DOI: 10.1002/ece3.2297.

809

810 Peckarsky BL. 1982. Aquatic insect predator-prey relations. BioScience 32:261-266. DOI:

811 https://doi.org/10.2307/1308532.

812

813 Petit RJ, Excoffier L. 2009. Gene flow and species delimitation. Trends in Ecology and 814 Evolution 24:386-393. DOI: 10.1016/j.tree.2009.02.011. 
815

816 Pfenning B, Poethke HJ. 2006. Variability in the life history of the water strider Gerris lacustris

817 (Heteroptera: Gerridae) across small spatial scales. Ecological Entomology 31:123-130. DOI:

818 10.1111/j.0307-6946.2006.00763.x.

819

820 Polhemus JT, Polhemus DA. 2008. Global diversity of true bugs (Heteroptera; Insecta) in

821 freshwater. Hydrobiologia 595:379-391. DOI: https://doi.org/10.1007/s10750-007-9033-1.

822

823 Ratnasingham S, Hebert PD. 2007. BOLD: The Barcode of Life Data System

824 (www.barcodinglife.org). Molecular Ecology Notes 7:355-364. DOI: 10.1111/j.1471-

825 8286.2007.01678.x.

826

827 Ratnasingham S, Hebert PD. 2013. A DNA-based registry for all animal species: The Barcode

828 Index Number (BIN) system. PLoS ONE 8:e66213. DOI:

829 https://doi.org/10.1371/journal.pone.0066213.

830

831 Raupach MJ, Astrin JJ, Hannig K, Peters MK, Stoeckle MY, Wägele J-W. 2010. Molecular

832 species identification of Central European ground beetles (Coleoptera: Carabidae) using nuclear 833 rDNA expansion segments and DNA barcodes. Frontiers in Zoology 7:26. DOI:

834 https://doi.org/10.1186/1742-9994-7-26.

835

836 Raupach MJ, Hendrich L, Küchler SM, Deister F, Morinière J, Gossner MM. 2014. Building-up 837 of a DNA barcode library for true bugs (Insecta: Hemiptera: Heteroptera) of Germany reveals 
838 taxonomic uncertainties and surprises. PLoS ONE 9:e106940. DOI:

839 https://doi.org/10.1371/journal.pone.0106940.

840

841 Raupach MJ, Radulovici AE. 2015. Looking back on a decade of barcoding crustaceans.

842 ZooKeys 539:53-81. DOI: 10.3897/zookeys.539.6530.

843

844 Raupach MJ, Barco A, Steinke D, Beermann J, Laakmann S, Mohrbeck I, Neumann H, Kihara

845 TC, Pointner K, Radulovici A, Segelken-Voigt A, Wesse C, Knebelsberger T. 2015. The

846 application of DNA barcodes for the identification of marine crustaceans from the North Sea and

847 adjacent regions. PLoS ONE 10:e0139421. DOI: https://doi.org/10.1371/journal.pone.0139421.

848

849 Raupach MJ, Amann R, Wheeler QD, Roos C. 2016. The application of "-omics" technologies 850 for the classification and identification of animals. Organisms, Diversity \& Evolution 16:1-12. 851 DOI: $10.1007 / \mathrm{s} 13127-015-0234-6$.

852

853 Rebijith KB, Asokan R, Kumar NK, Srikumar KK, Ramamurthy VV, Bhat PS. 2012. DNA

854 barcoding and development of species-specific markers for the identification of tea mosquito

855 bugs (Miridae: Heteroptera) in India. Environmental Entomology 41:1239-1245. DOI:

856 10.1603/EN12096.

857

858 Saitou N, Nei M. 1987. The Neighbor-joining method: A new method for reconstructing 859 phylogenetic trees. Molecular Biology and Evolution 4:406-425. DOI:

860 https://doi.org/10.1093/oxfordjournals.molbev.a040454. 
861

862 Savage AA. 1989. Adults of British aquatic Hemiptera Heteroptera: A key with ecological notes.

863 Freshwater Biological Association Scientific Publications 50:1-173.

864

865 Savage A, Parkin E. 1998. The diagnostic features of British Sigara striata, S. dorsalis and 866 intermediate specimens (Corixidae), with a new key for identification of adult males. Freshwater 867 Forum 10:35-48. DOI: http://aquaticcommons.org/id/eprint/4589.

868

869 Scheffers BR, Joppa LN, Pimm SL, Laurance WF. 2012. What we know and don't know about 870 Earth's missing biodiversity. Trends in Ecology \& Evolution 27:501-510. DOI:

871 10.1016/j.tree.2012.05.008.

872

873 Schuh RT, Slater JA. 1995. True Bugs of the World (Hemiptera: Heteroptera): Classification 874 and Natural History. Ithaca: Cornell University Press.

875

876 Schuster G. 1983. Zur Trennung von Gerris lateralis Schumm. und Gerris asper Fieb. Bericht 877 der Naturforschenden Gesellschaft Augsburg 38:3-6. (in German)

878

879 Shackleton M, Rees GN. 2015. DNA barcoding Australian macroinvertebrates for monitoring 880 programs: benefits and current short comings. Marine and Freshwater Research 67:380-390.

881 DOI: https://doi.org/10.1071/MF14331.

882 
883 Simon C, Frati F, Beckenbach A, Crespi B, Liu H, Flook P. 1994. Evolution, weighting, and

884 phylogenetic utility of mitochondrial gene sequences and a compilation of conserved polymerase

885 chain reaction primers. Annals of the Entomological Society of America 87:651-701. DOI:

886 https://doi.org/10.1093/aesa/87.6.651.

887

888 Skern M, Zweimüller I, Schiemer F. 2010. Aquatic Heteroptera as indicators for terrestrialisation 889 of floodplain habitats. Limnologica - Ecology and Management of Inland Waters 40:241-250.

890 DOI: https://doi.org/10.1016/j.limno.2009.09.002.

891

892 Song H, Moulton MJ, Whiting MF. 2014. Rampant nuclear insertion of mtDNA across diverse

893 lineages within Orthoptera (Insecta). PLoS ONE 9:e110508. DOI:

894 https://doi.org/10.1371/journal.pone.0110508.

895

896 Soós N, Petri A, Nagy-László Z, Csabai. 2010. Anisops sardeus Herrich-Schaeffer, 1849: first 897 records from Hungary (Heteroptera: Notonectidae). Folia Entomologica Hungarica 71:15-18. 898

899 Spelda J, Reip HS, Oliveira-Biener U, Melzer RR. 2011. Barcoding Fauna Bavarica: Myriapoda 900 - a contribution to DNA sequence-based identifications of centipedes and millipedes (Chilopoda, 901 Diplopoda). ZooKeys 156:123-139. DOI: http://doi.org/10.3897/zookeys.156.2176.

902

903 Spence JR, Wilcox RS. 1986. The mating system of two hybridizing species of water striders 904 (Gerridae). II. Alternative tactics of males and females. Behavioral Ecology and Sociobiology 905 19:87-95. DOI: https://doi.org/10.1007/BF00299943. 
906

907 Spence JR, Andersen NM. 1994. Biology of water striders - interactions between systematics 908 and ecology. Annual Review of Entomology 39:101-128. DOI:

909 https://doi.org/10.1146/annurev.en.39.010194.000533.

910

911 Stoffelen E, Henderickx H, Vercauteren T, Lock K, Bosmans R. 2013. De water- en 912 oppervlaktewantsen van België. Brussel: Koninklich Belgisch Instituut voor

913 Natuurwetenschappen. (in Dutch)

914

915 Strauss G, Niedringhaus R. 2014. Die Wasserwanzen Deutschlands - Bestimmungsschlüssel für 916 alle Nepo- und Gerromorpha. Scheeßel: WABV. (in German)

917

918 Tautz D, Arctander P, Minelli A, Thomas RH, Vogler AP. 2003. A plea for DNA taxonomy.

919 Trends in Ecology and Evolution 18:70-74. DOI: https://doi.org/10.1016/S0169-5347(02)000419201.

921

922 Tembe S, Shouche Y, Ghate HV. DNA barcoding of Pentatomorpha bugs (Hemiptera:

923 Heteroptera) from Western Ghats of India. Meta Gene 2:737-745. DOI:

924 10.1016/j.mgene.2014.09.006.

925

926 Wachmann E, Melber A, Deckert J. 2006. Die Tierwelt Deutschlands 77. Teil. Wanzen Band 1.

927 Dipsocoromorpha, Nepomorpha, Gerromorpha, Leptopodomorpha, Cimicomorpha (Teil 1).

928 Keltern: Goecke \& Evers. (in German) 
929

930 Wagner E, Zimmermann S. 1955. Beitrag zur Systematik der Gattung Gerris F. (Hemiptera931 Heteroptera, Gerridae). Zoologischer Anzeiger 155:177-190. (in German)

932

933 Werren JH, Zhang W, Guo LR. 1995. Evolution and phylogeny of Wolbachia: reproductive 934 parasites of arthropods. Proceedings of the Royal Society B: Biological Sciences 261:55-71 DOI:

$93510.1098 /$ rspb.1995.0117.

936

937 Werren JH, Baldo L, Clark ME. 2008. Wolbachia: master manipulators of invertebrate biology. 938 Nature Reviews 6:741-751. DOI: 10.1038/nrmicro1969.

939

940 Wesenberg-Lund C. 1943. Biologie der Süßwasserinsekten (Reprint). Luxenburg: Springer. (in

941 German)

942

943 Whiteman NK, Sites RW. 2008. Aquatic insects as umbrella species for ecosystem protection in

944 Death Valley National Park. Journal of Insect Conservation 12:499-509. DOI: 10.1007/s10841$945 \quad 007-9090-9$.

946

947 Wilcox RS, Spence JR. 1986. The mating system of two hybridizing species of water striders

948 (Gerridae). I. Ripple signal functions. Behavioral Ecology and Sociobiology 19:79-85. DOI:

949 https://doi.org/10.1007/BF00299942.

950 
951 Xiao J-H, Wang N-X, Murphy RW, Cook J, Jia L-Y, Huang D-W. 2011. Wolbachia infection

952 and dramatic intraspecific mitochondrial DNA divergence in a fig wasp. Evolution 66:1907-

953 1916. DOI: $10.1111 /$ j.1558-5646.2011.01561.x.

954

955 Ye Z, Zhu G, Damgaard J, Chen X. Chen P, Bu W. 2016. Phylogeography of a semi-aquatic bug,

956 Microvelia horvathi (Hemiptera: Veliidae): an evaluation of historical, geographical and

957 ecological factors. Scientific Reports 6:21932. DOI: 10.1038/srep21932.

958

959 Zera AJ, Innes DJ, Saks ME. 1983. Genetic and environmental determinants of wing 960 polymorphism in the waterstrider Limnoporus canaliculatus. Evolution 31:513-522. DOI:

$961 \quad 10.2307 / 2408264$.

962

963 Zhou C, Kandemir I, Walsh DB, Zalom FG, Lavine LC. 2012. Identification of Lygus hesperus

964 by DNA barcoding reveals insignificant levels of genetic structure among distant and habitat 965 diverse populations. PLoS ONE 7:e34528. DOI: https://doi.org/10.1371/journal.pone.0034528.

966

967 Zimmermann, Spence JR. 1989. Prey use of the fishing spider Dolomedes triton (Pisauridae, 968 Araneae): an important predator of the neuston community. Oecologia 80:187-194. DOI:

969 10.1007/BF00380149. 


\section{Figure 1 (on next page)}

Representative images of analyzed aquatic bug species.

A: Nepa cinerea Linnaeus, 1758 (Nepidae), B: Corixa affinis Leach, 1817 (Corixidae), C:

Sigara (Subsigara) scotti (Douglas \& Scott, 1868) (Corixidae), D: llyocoris cimicoides (Linnaeus, 1758) (Naucoridae), E: Aphelocheirus aestivalis (Fabricius, 1794)

(Aphelocheiridae), F: Notonecta viridis Delcourt, 1909 (Notonectidae), G: Plea minutissima Leach, 1817 (Pleidae), H: Mesovelia furcata Mulsant \& Rey, 1852 (Mesovelidae), I: Hydrometra gracilenta Horváth, 1899 (Hydrometridae), J: Hebrus ruficeps Thompson, 1871 (Hebridae), K: Velia caprai Tamanini, 1947 (Velidae), L: Gerris costae (Herrich-Schaeffer, 1850) (Gerridae). Scale bars $=1 \mathrm{~mm}$. All images were obtained from www.corisa.de. 


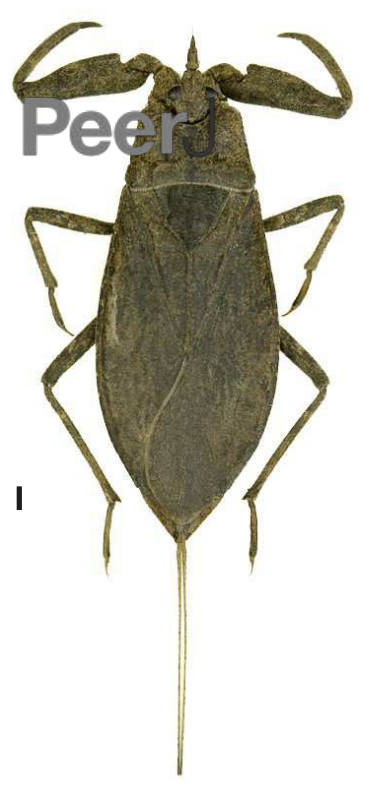

A
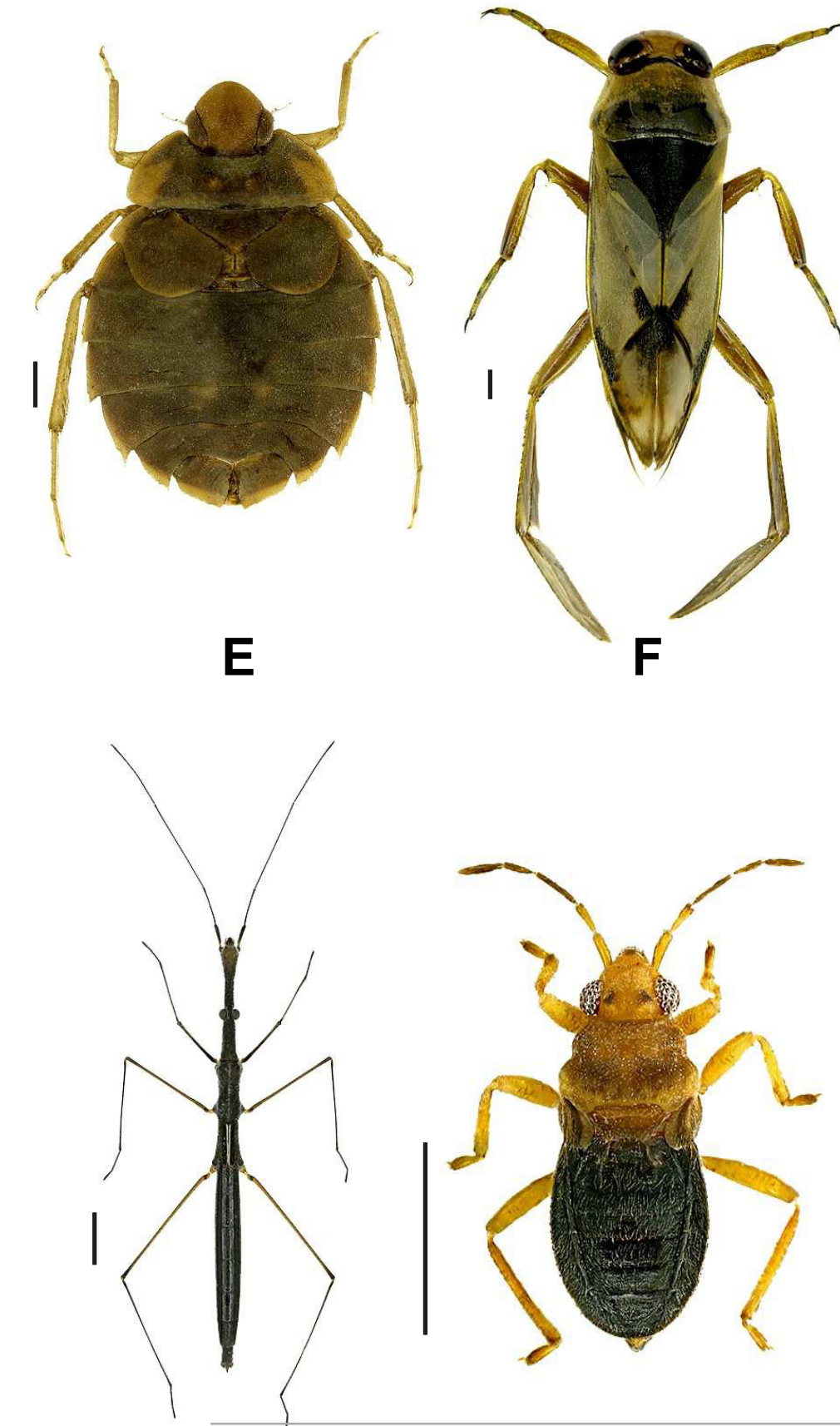

Peer] reviewing PDF | (2017:12:22312:2:0:NEW 12 Mar 2018) I

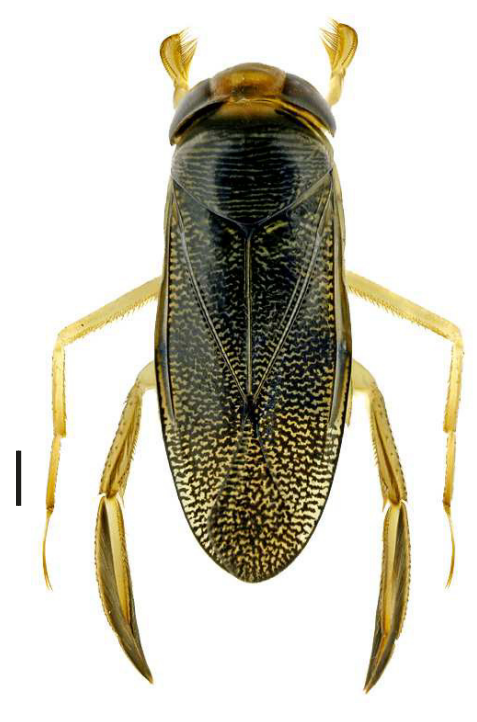

B

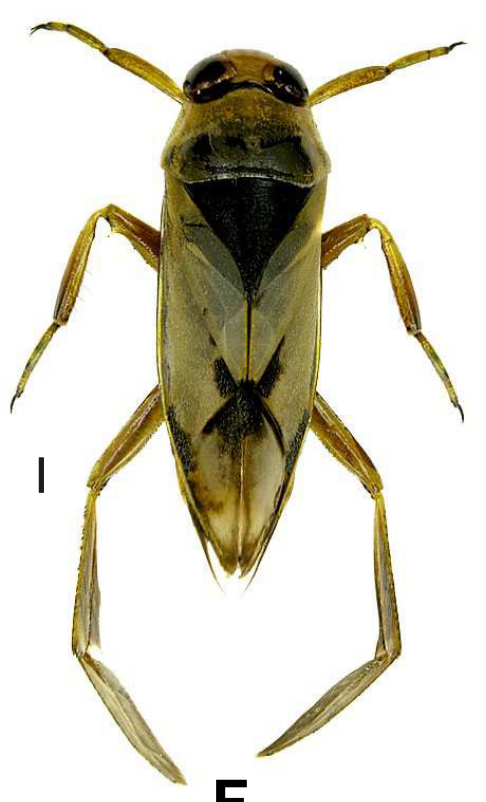

$\mathbf{F}$

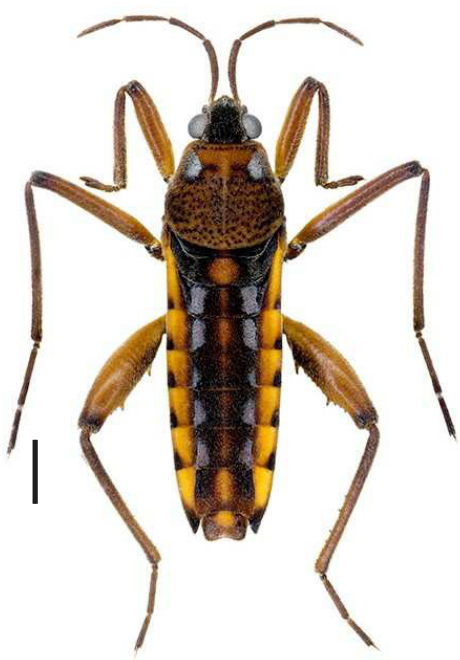

K

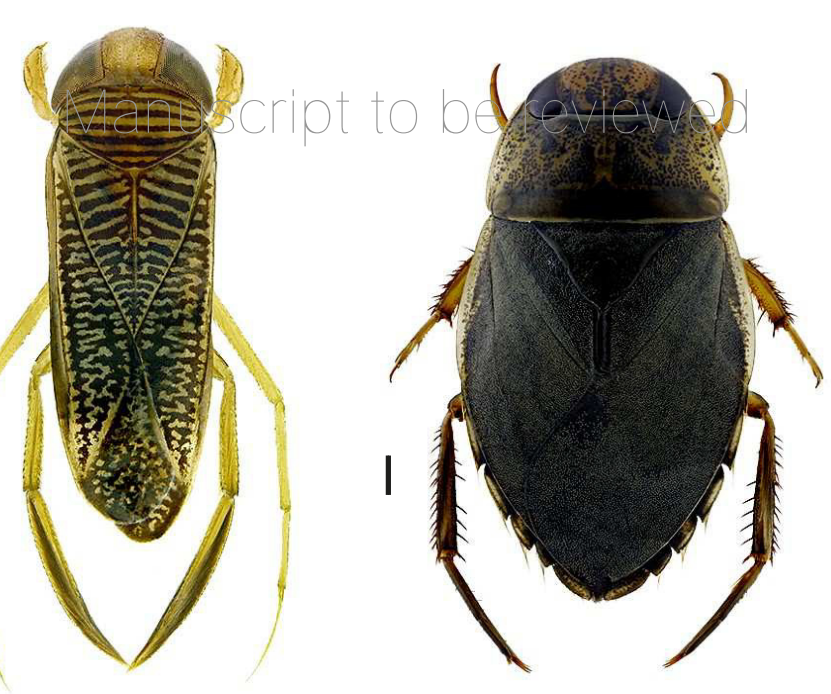

C

D

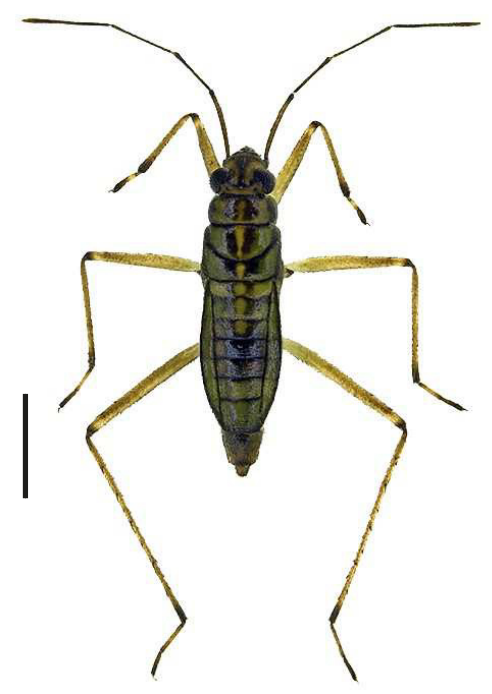

G

H

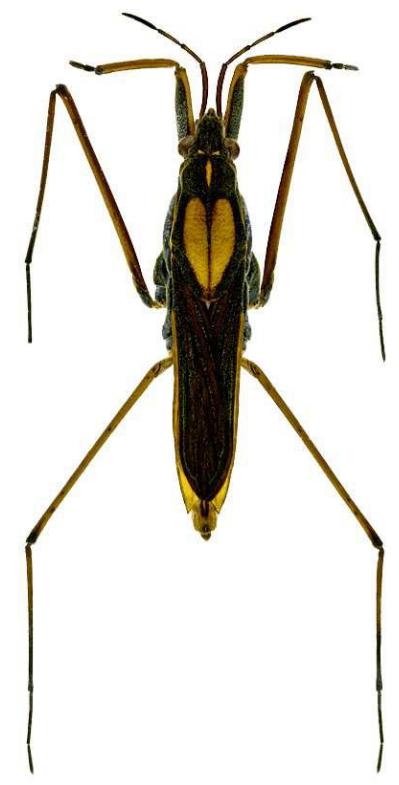


Figure 2

Sampling sites of the studied aquatic true bugs (Gerromorpha, Nepomorpha) across Europe.

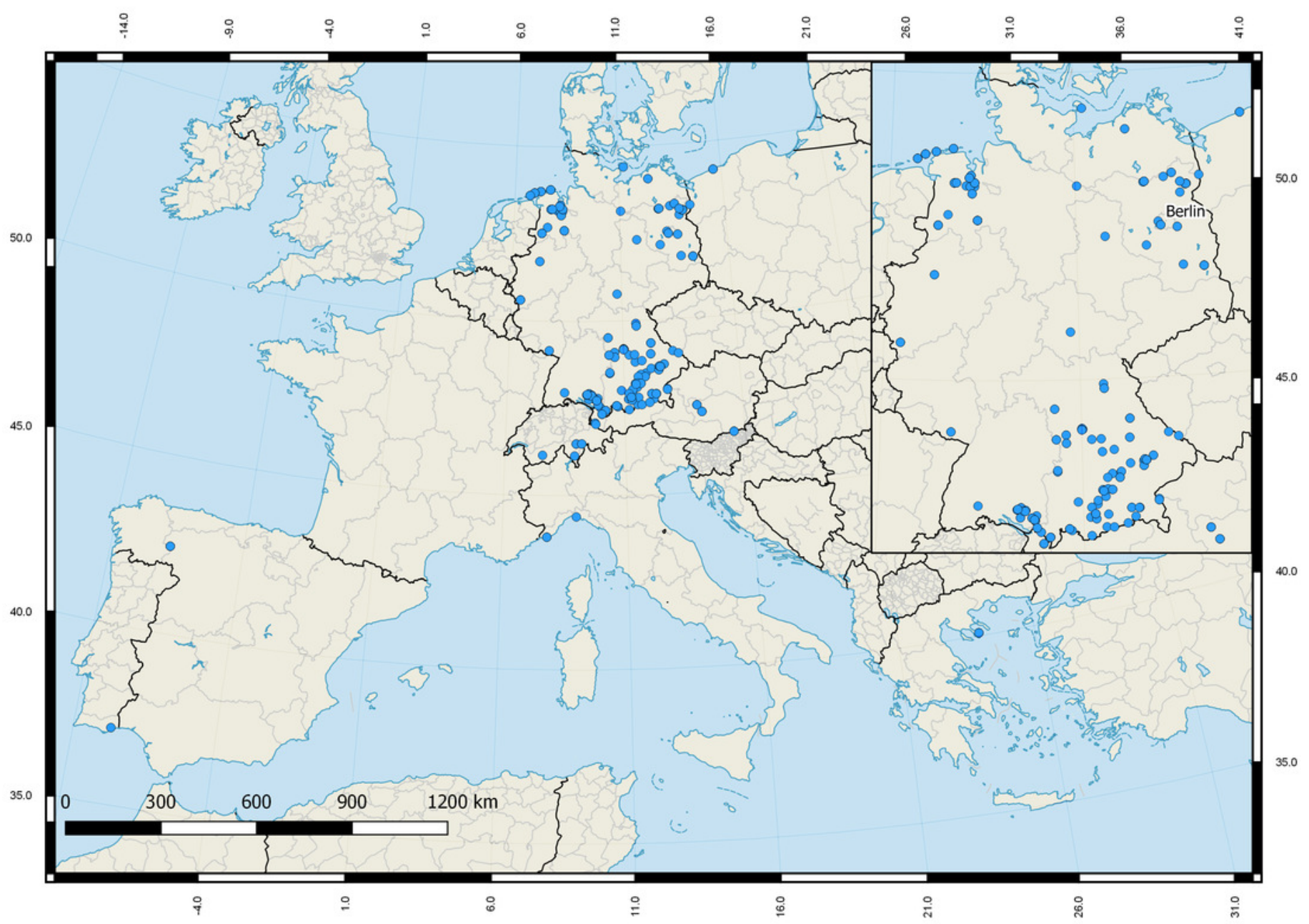


Figure 3 (on next page)

Neighbor Joining (NJ) topology of the analyzed species of the Gerromorpha based on Kimura 2-parameter distance.

Triangles indicate the relative number of individual's sampled (height) and sequence divergence (width). Blue triangles indicate species with intraspecific maximum pairwise distances $>2.2 \%$, red triangles species pairs with interspecific distances $<2.2 \%$. Numbers next to nodes represent non-parametric bootstrap values $>80 \%$ ( 1,000 replicates). Asterisks indicate species not recorded in Germany. All images were obtained from www.corisa.de. 


\section{PeerJ}

Gerris lacustris

\section{Manuscript to be reviewed}

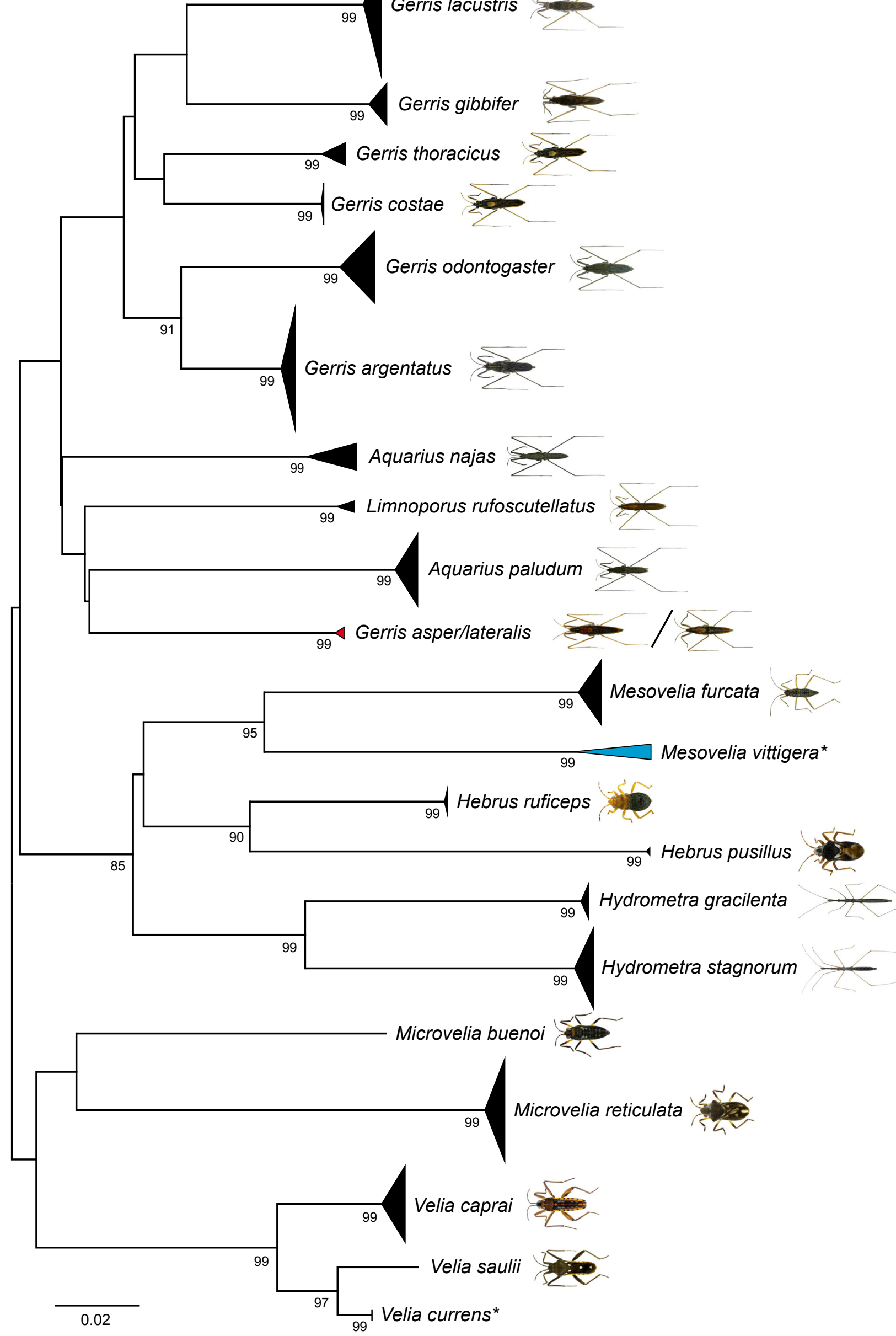


Figure 4 (on next page)

Neighbor Joining (NJ) topology of the analyzed species of the Nepomorpha based on Kimura 2-parameter distance.

Triangles indicate the relative number of individual's sampled (height) and sequence divergence (width). Blue triangles indicate species with intraspecific maximum pairwise distances $>2.2 \%$, red triangles species with interspecific distances $<2.2 \%$. Numbers next to nodes represent non-parametric bootstrap values $>=80 \%$ (1,000 replicates). Asterisks indicate species not recorded in Germany. All images were obtained from www.corisa.de. 


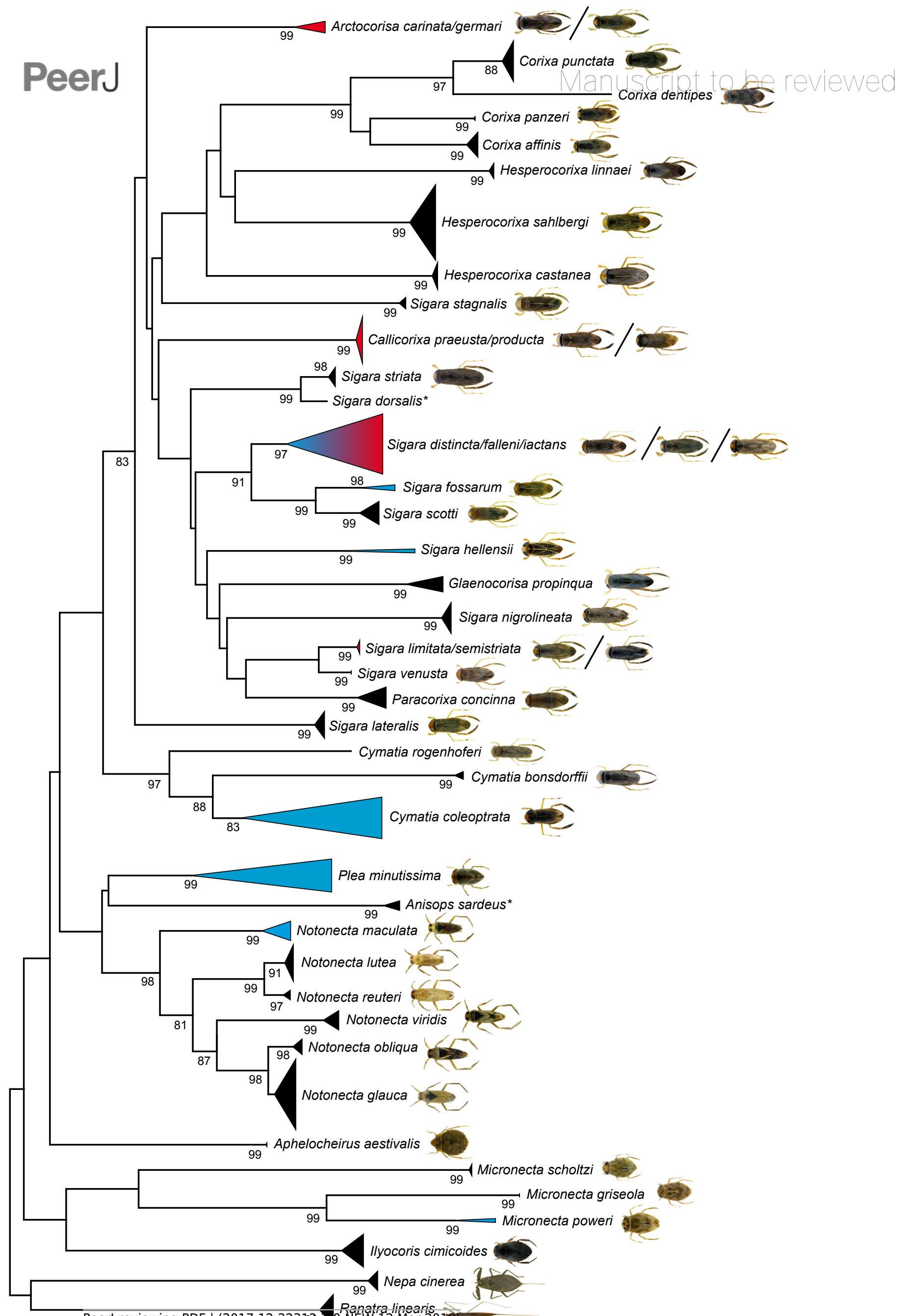

Peer) reviewing PDF | (2017:12:223192:2_0:NEW 12 Mar 2018) 


\section{Figure 5 (on next page)}

Maximum statistical parsimony network of various species of the Gerromorpha and Nepomorpha with interspecific K2P-based distances of COI sequences $<1 \%$.

A Gerris asper (Fieber, 1860) $(n=1)$ and Gerris lateralis Schummel, $1832(n=2)$; B Sigara limitata (Fieber, 1848) $(n=2)$ and Sigara semistriata (Fieber, 1848$)(n=5)$; C Callicorixa praeusta (Fieber, 1848) $(n=23)$ and Callicorixa producta (Reuter, 1880) $(n=1)$. Used settings included default settings for connection steps whereas gaps were treated as fifth state. Each line represents a single mutational change whereas small black dots and small black lines indicate missing haplotypes. The diameter of the circles is proportional to the number of haplotypes sampled (see open half circles with numbers). Color codes were given for each species. Scale bars $=1 \mathrm{~mm}$. Aquatic bug images were obtained from www.corisa.de. 


\section{$A^{\text {PeerJ }}$}
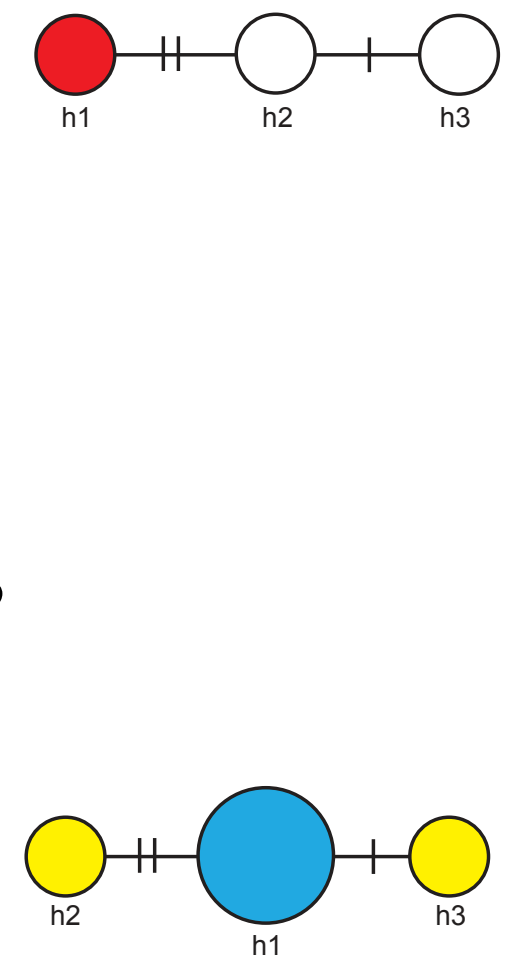

B

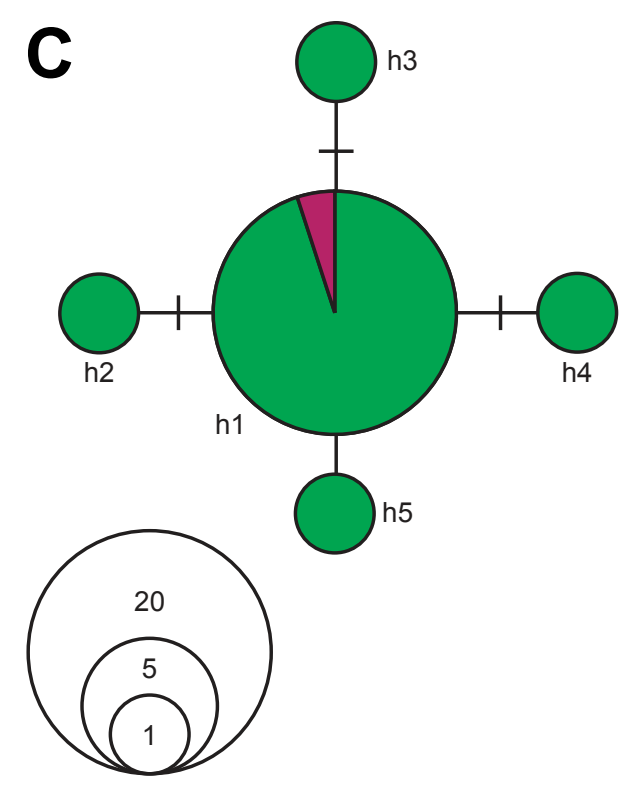

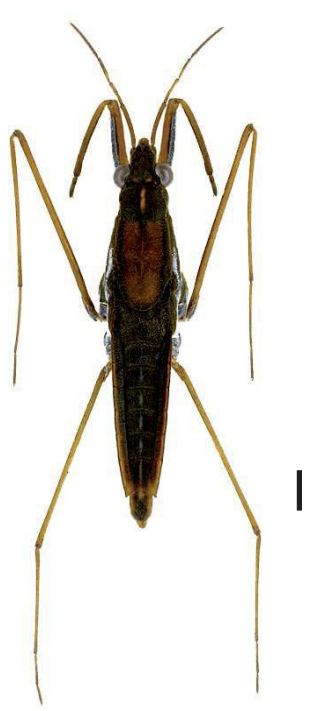

Gerris asper (Fieber, 1860) $(n=1)$

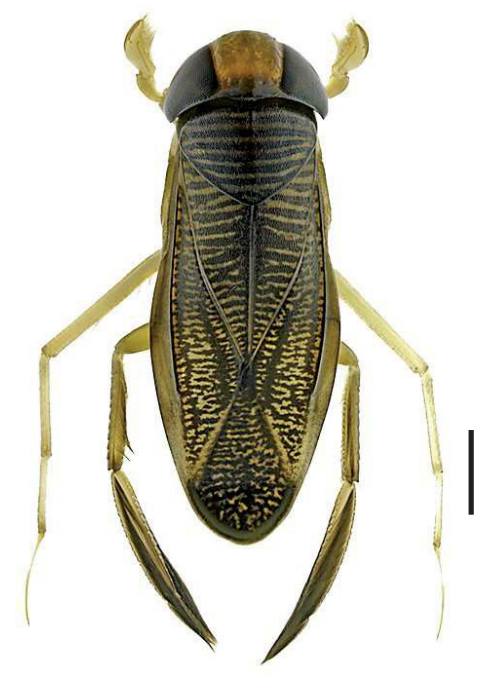

Sigara limitata (Fieber, 1848) $(n=2)$

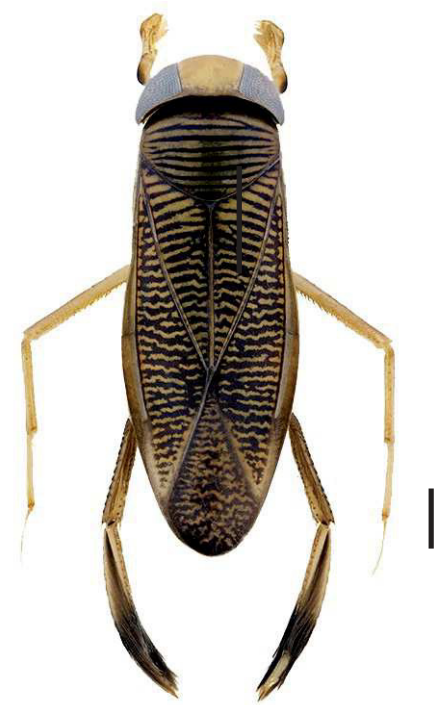

Callicorixa praeusta (Fieber, 1848) $(n=23)$
Manuscript to be rexiewed

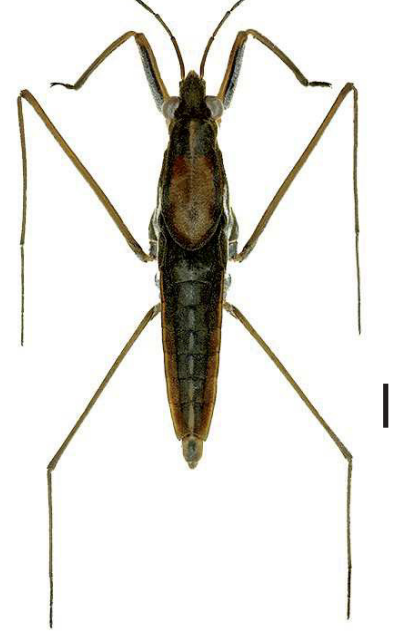

Gerris lateralis Schummel, 1832 $(n=2)$

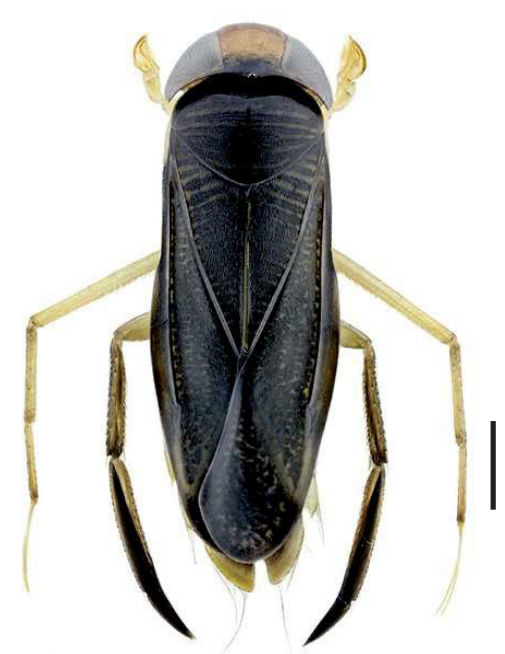

Sigara semistriata (Fieber, 1848) $(n=5)$

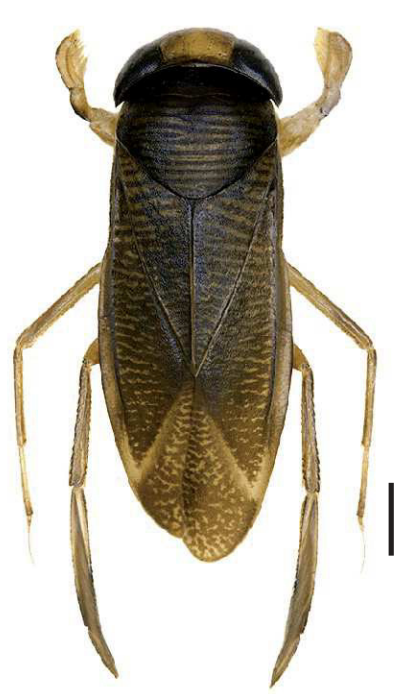

Callicorixa producta (Reuter, 1880) $(n=1)$ 


\section{Figure 6 (on next page)}

Maximum statistical parsimony network of three Sigara species with interspecific K2Pbased distances of $\mathrm{COI}$ sequences $<1 \%$.

Used settings included default settings for connection steps whereas gaps were treated as fifth state. Each line represents a single mutational change whereas small black dots and small black lines indicate missing haplotypes. The diameter of the circles is proportional to the number of haplotypes sampled (see open half circles with numbers). Color codes were given for each species. Scale bars $=1 \mathrm{~mm}$. Aquatic bug images were obtained from www.corisa.de. 


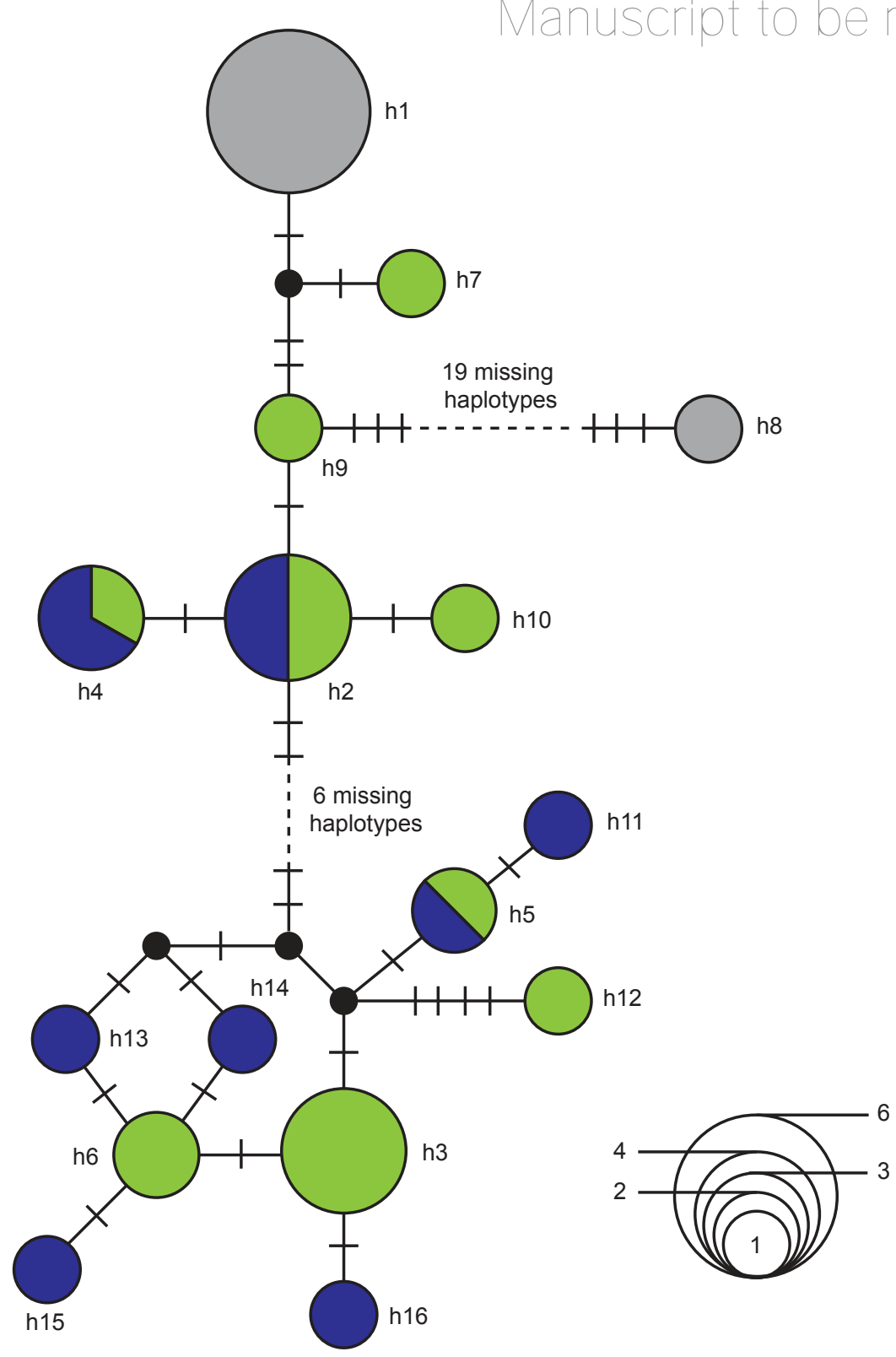

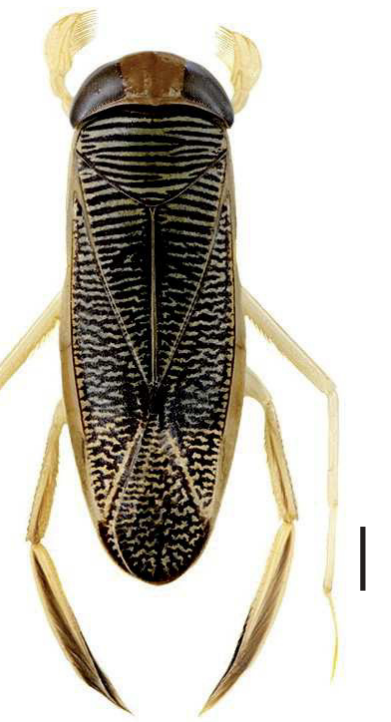

Sigara distincta (Fieber, 1848) $(n=7)$

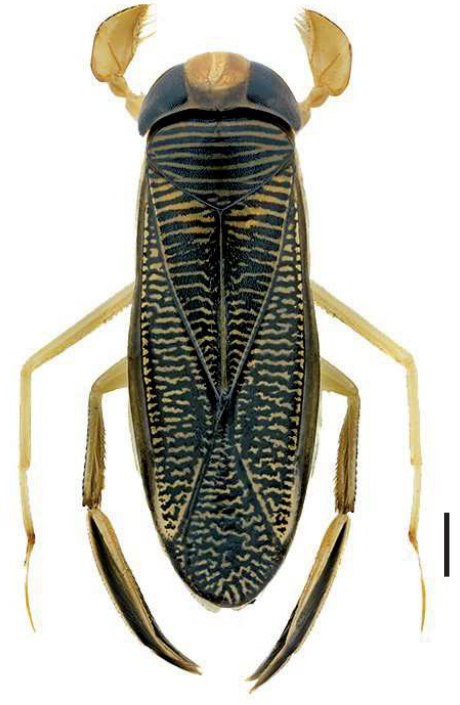

Sigara falleni (Fieber, 1848) $(n=12)$

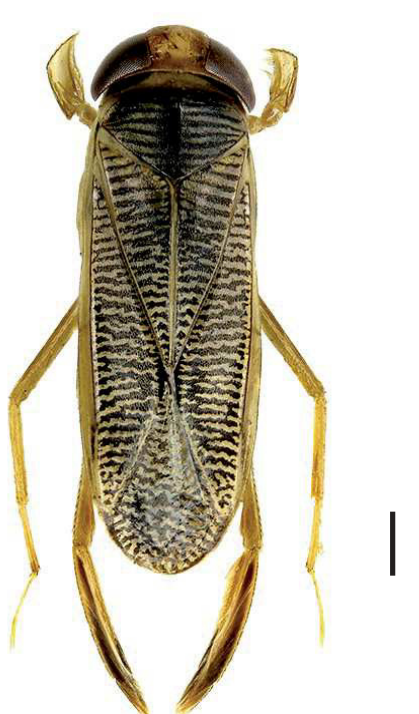

Sigara iactans Jansson, 1983 $(n=12)$ 
Figure 7 (on next page)

Subtree of the Neighbour Joining topology of the analyzed specimens of Plea minutissima Leach, 1817.

Branches with specimen ID-Number from BOLD and species names. Numbers next to internal branches are non-parametric bootstrap values (in \%). Scale bar $=1 \mathrm{~mm}$. Image obtained from www.corisa.de. 


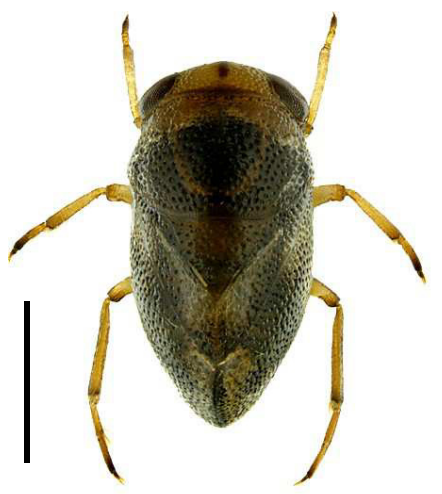

BCEAB523-17 Plea minutissima (Bavaria, Thürnthenning) BCEAB522-17 Plea minutissima (Bavaria, Thürnthenning) BCEAB524-17 Plea minutissima (Bavaria, Thürnthenning) BCEAB563-17 Plea minutissima (Brandenburg, Cottbus) BCEAB564-17 Plea minutissima (Brandenburg, Cottbus) FBAQU022-09 Plea minutissima (Bavaria, Traunstein) BCEAB444-16 Plea minutissima (Brandenburg, Cottbus) BCEAB416-16 Plea minutissima (Lower Saxony, Jaderberg) BCEAB414-16 Plea minutissima (Lower Saxony, Jaderberg) BCEAB505-17 Plea minutissima (Lower Saxony, Norderney) BCEAB485-17 Plea minutissima (Lower Saxony, Lingen) BCEAB475-17 Plea minutissima (Lower Saxony, Lingen) BCEAB377-16 Plea minutissima (Lower Saxony, Norderney) BCEAB375-16 Plea minutissima (Lower Saxony, Norderney) BCEAB413-16 Plea minutissima (Lower Saxony, Jaderberg) BCEAB478-17 Plea minutissima (Lower Saxony, Lingen) BCEAB476-17 Plea minutissima (Lower Saxony, Lingen)

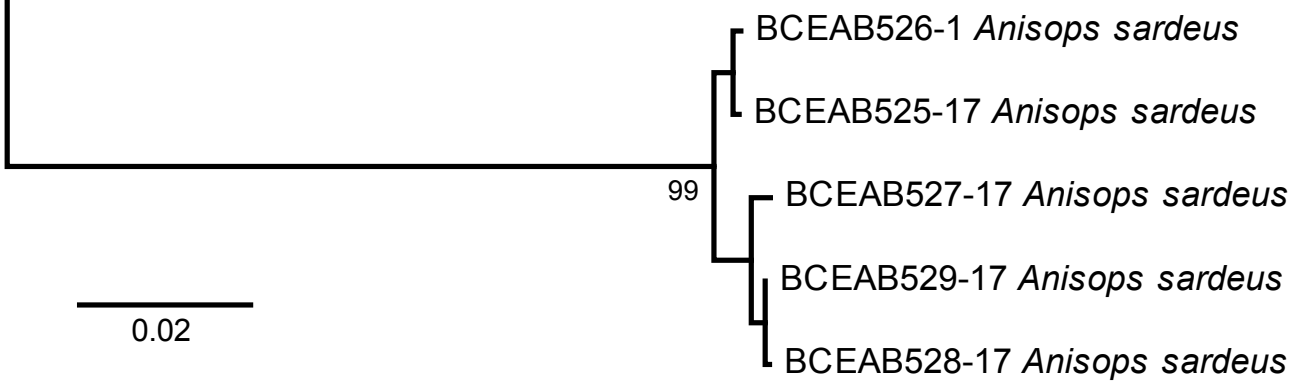


Figure 8 (on next page)

Subtree of the Neighbour Joining topology of the analyzed species of the genus Cymatia Flor, 1860.

Numbers next to internal branches are non-parametric bootstrap values (in \%). Images obtained from www.corisa.de. 


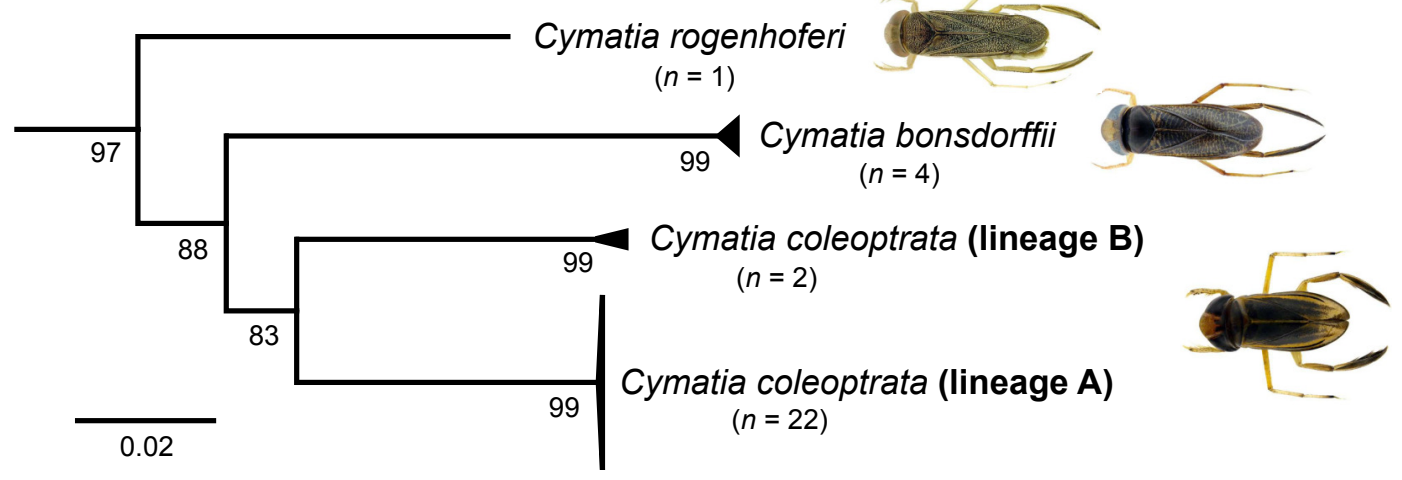




\section{Table $\mathbf{1}$ (on next page)}

BOLD distance analysis of the studied Gerromorpha and Nepomorpha.

With the number of analyzed specimens ( $n$ ), phylogenetic categories (PC), barcode index number (BIN), maximum intraspecific pairwise K2P distances (MID), minimum interspecific pairwise K2P distances to the nearest neighbor species (DNN), and the nearest neighbor species (NNS). Maximum intraspecific distances $>2.2 \%$ and minimum interspecific distances $<2.2 \%$ are marked in bold. At least one specimen of the compared species showed a distance value above or below this threshold in terms of a pairwise comparison. Asterisks $(*)$ indicate species not recorded for Germany 


\begin{tabular}{|c|c|c|c|c|c|c|c|}
\hline Family & Species & $n$ & PC & BIN & MID & DNN & NNS \\
\hline Aphelocheiridae & Aphelocheirus aestivalis & 2 & mono & ABX0398 & 0 & 11.86 & Notonecta maculata \\
\hline \multirow[t]{33}{*}{ Corixidae } & Arctocorisa carinata & 5 & para & AAJ7903, ACY1261 & 2.36 & 1.03 & Arctocorisa germari \\
\hline & Arctocorisa germari & 1 & n. a. & - & 0 & 1.03 & Arctocorisa carinata \\
\hline & Callicorixa praeusta & 23 & para & AAK1938 & 0.31 & 0 & Callicorixa producta \\
\hline & Callicorixa producta & 1 & n. a. & AAK1938 & 0 & 0 & Callicorixa praeusta \\
\hline & Corixa affinis & 13 & mono & ACY0615 & 1.92 & 5.92 & Corixa panzeri \\
\hline & Corixa dentipes & 1 & n. a. & - & 0 & 6.08 & Corixa punctata \\
\hline & Corixa panzeri & 2 & mono & ACX9506 & 0 & 5.92 & Corixa affinis \\
\hline & Corixa punctata & 21 & mono & ACB1799 & 0.77 & 6.08 & Corixa dentipes \\
\hline & Cymatia bonsdorffii & 4 & mono & ABX0396 & 0.62 & 12.34 & Cymatia coleoptrata \\
\hline & Cymatia coleoptrata & 24 & mono & ACB1796, ADD1561 & 9.44 & 12.4 & Cymatia bonsdorffii \\
\hline & Cymatia rogenhoferi & 1 & n. a. & ACB2132 & 0 & 12.7 & Cymatia coleoptrata \\
\hline & Glaenocorisa propinqua & 8 & mono & ABX4248 & 1.55 & 9.96 & Sigara semistriata \\
\hline & Hesperocorixa castanea & 14 & mono & $\mathrm{ABX0447}$ & 0.32 & 13.22 & Paracorixa concinna \\
\hline & Hesperocorixa linnaei & 8 & mono & $A B X 0448$ & 0 & 11.89 & Sigara venusta \\
\hline & Hesperocorixa sahlbergi & 39 & mono & AAN0795 & 1.7 & 11.34 & Corixa panzeri \\
\hline & Micronecta griseola & 2 & mono & AAK6480 & 0 & 10.63 & Micronecta poweri \\
\hline & Micronecta poweri & 2 & mono & ACB1970 & 2.39 & 10.63 & Micronecta griseola \\
\hline & Micronecta scholtzi & 6 & mono & AAK6479 & 0.16 & 18.58 & Sigara semistriata \\
\hline & Paracorixa concinna & 11 & mono & ABV3365, ADG5371 & 1.71 & 7.03 & Sigara semistriata \\
\hline & Sigara distincta & 7 & poly & ABY7152, ABV4484 & 5.77 & 0.37 & Sigara falleni \\
\hline & Sigara dorsalis* & 1 & n. a. & AAJ6688 & 0 & 1.71 & Sigara striata \\
\hline & Sigara falleni & 12 & poly & AAH9524, ABY7152 & 3.37 & 0 & Sigara iactans \\
\hline & Sigara fossarum & 3 & mono & AAJ6707, ADD1512 & 2.82 & 2.72 & Sigara scotti \\
\hline & Sigara hellensii & 2 & mono & ADH9592, ACT7694 & 4.41 & 9.09 & Sigara distincta \\
\hline & Sigara iactans & 12 & poly & ABY7152, AAH9524 & 2.67 & 0 & Sigara falleni \\
\hline & Sigara lateralis & 14 & mono & AAJ6697 & 0.81 & 9.84 & Sigara striata \\
\hline & Sigara limitata & 2 & para & ACM1221 & 0.48 & 0.15 & Sigara semistriata \\
\hline & Sigara nigrolineata & 16 & mono & ACB1978 & 0.46 & 10.12 & Sigara semistriata \\
\hline & Sigara scotti & 12 & mono & ACY0807 & 1.08 & 2.72 & Sigara fossarum \\
\hline & Sigara semistriata & 5 & poly & ACM1221 & 0 & 0.15 & Sigara limitata \\
\hline & Sigara stagnalis & 6 & mono & ACY0713 & 0.55 & 11.45 & Paracorixa concinna \\
\hline & Sigara striata & 10 & mono & AAJ6688 & 0.93 & 1.71 & Sigara dorsalis \\
\hline & Sigara venusta & 2 & mono & ABA5309 & 0 & 2.11 & Sigara semistriata \\
\hline Naucoridae & Ilyocoris cimicoides & 17 & mono & AAF2590 & 1.03 & 15.06 & Hesperocorixa sahlbergi \\
\hline \multirow[t]{2}{*}{ Nepidae } & Nepa cinerea & 10 & mono & AAK8359 & 0.34 & 17.06 & Notonecta maculata \\
\hline & Ranatra linearis & 16 & mono & AAL1328 & 0.84 & 15.03 & Notonecta lutea \\
\hline \multirow[t]{7}{*}{ Notonectidae } & Anisops sardeus* & 5 & mono & ABV0079 & 1.24 & 12.84 & Notonecta maculata \\
\hline & Notonecta glauca & 41 & mono & AAK4442 & 1.71 & 1.08 & Notonecta obliqua \\
\hline & Notonecta lutea & 19 & mono & AAN1701 & 0.68 & 1.24 & Notonecta reuteri \\
\hline & Notonecta maculata & 10 & mono & AAN1703 & 2.43 & 6.56 & Notonecta glauca \\
\hline & Notonecta obliqua & 9 & mono & AAK4442 & 0.64 & 1.08 & Notonecta glauca \\
\hline & Notonecta reuteri & 5 & mono & ACE8526 & 0.46 & 1.24 & Notonecta lutea \\
\hline & Notonecta viridis & 10 & mono & ABV0133 & 1.18 & 5.03 & Notonecta glauca \\
\hline Pleidae & Plea minutissima & 17 & mono & ACY0868, AAF3832 & 8.3 & 10.92 & Notonecta lutea \\
\hline \multirow[t]{5}{*}{ Gerridae } & Aquarius najas & 7 & mono & AAN1521 & 2.14 & 11.75 & Gerris thoracicus \\
\hline & Aquarius paludum & 19 & mono & AAl7450 & 1.24 & 12.61 & Gerris argentatus \\
\hline & Gerris argentatus & 32 & mono & ADD1846 & 0.72 & 6.55 & Gerris odontogaster \\
\hline & Gerris asper & 1 & n. a. & ABA3327 & 0 & 0.34 & Gerris lateralis \\
\hline & Gerris costae & 11 & mono & $\mathrm{ACl} 6181$ & 0 & 7.48 & Gerris thoracicus \\
\hline
\end{tabular}




\begin{tabular}{|c|c|c|c|c|c|c|c|}
\hline & Gerris gibbifer & 11 & mono & ACB1756 & 0.88 & 8.91 & Gerris lacustris \\
\hline & Gerris lacustris & 38 & mono & АCT3584 & 1.05 & 8.91 & Gerris gibbifer \\
\hline & Gerris lateralis & 2 & mono & ABA3327 & 0.17 & 0.34 & Gerris asper \\
\hline & Gerris odontogaster & 19 & mono & ABU6679, ADD1838 & 1.59 & 6.55 & Gerris argentatus \\
\hline & Gerris thoracicus & 6 & mono & ACB1745 & 0.35 & 7.48 & Gerris costae \\
\hline & Limnoporus rufoscutellatus & 3 & mono & AAV0261 & 0.88 & 11.86 & Gerris asper \\
\hline \multirow[t]{2}{*}{ Hebridae } & Hebrus pusillus & 2 & mono & AAN0981 & 0.15 & 14.32 & Hebrus ruficeps \\
\hline & Hebrus ruficeps & 7 & mono & AAl6967 & 0.15 & 14.32 & Hebrus pusillus \\
\hline \multirow[t]{2}{*}{ Hydrometridae } & Hydrometra gracilenta & 9 & mono & AAN0857 & 0.46 & 13.06 & Hydrometra stagnorum \\
\hline & Hydrometra stagnorum & 21 & mono & AAK5632 & 0.62 & 13.06 & Hydrometra gracilenta \\
\hline \multirow[t]{2}{*}{ Mesoveliidae } & Mesovelia furcata & 17 & mono & AAN2451 & 1.39 & 16.24 & Mesovelia vittigera \\
\hline & Mesovelia vittigera* & 4 & mono & ACD4048 & 2.32 & 16.24 & Mesovelia furcata \\
\hline \multirow[t]{5}{*}{ Veliidae } & Microvelia buenoi & 1 & n. $a$. & ACY1789 & 0 & 15.06 & Gerris costae \\
\hline & Microvelia reticulata & 27 & mono & AAG4341 & 0.77 & 15.04 & Gerris asper \\
\hline & Velia caprai & 20 & mono & AAN0455 & 1.1 & 4.94 & Velia saulii \\
\hline & Velia currens ${ }^{*}$ & 3 & mono & ADI1962 & 0 & 2.82 & Velia saulii \\
\hline & Velia saulii & 1 & n. a. & ABX0836 & 0 & 2.82 & Velia currens \\
\hline
\end{tabular}

1 